Revista Iberoamericana, Vol. LXXX, Núm. 247, Abril-Junio 2014, 399-432

\title{
LECTURAS DE LA DERROTA Y EL FRACASO EN LA PRODUCCIÓN NARRATIVA Y CRÍTICA DE MARCELO COHEN
}

\author{
POR \\ Miriam Chiani \\ Universidad Nacional de La Plata
}

A partir de mediados de los ochenta, desde el autoexilio en España, Marcelo Cohen propone un nuevo tipo de realismo al que denomina "incierto" o "inseguro" (Cohen "Como si”). Con él quedan desplazados el contacto con un realismo social matizado con realismo mágico de sus primeras obras, y la confianza en el carácter representativocrítico de la literatura, su valor gnoseológico y su posible efectividad se reelaboran.

Con esta categoría pretende neutralizar o limar la distinción entre el realismo y lo fantástico para dar lugar a una síntesis que corroe ambas legalidades genéricas y demostrar cómo podría funcionar o funciona la literatura, la narración en general, más allá de las diferencias o polaridades que si bien pueden tener su fundamento en procedimientos técnicos y morales, son frustrantes en tanto moldes/clausuras/mitos, obturantes de la posibilidad de que algo nuevo surja en el proceso de contar. En este sentido, la literatura de Cohen sería un caso más de las "escrituras desdiferenciadoras" que comienzan a distinguirse a partir de 1990 y se caracterizan precisamente por establecer fusiones y combinaciones múltiples entre formas, estilos, categorías que tradicionalmente se oponían. ${ }^{1}$

Sobre la base de este proyecto, en los textos producidos a partir especialmente de la década del noventa, Cohen presenta espacios virtuales distópicos, fantasías anticipativas paranoicas que son términos extremos de nuestras propias leyes y tienen puntos de contactos con la tendencia, que iniciada por el ruso Eugene Zamiatin en 1920, consolidaron Huxley, Orwell, Bradbury, como una de las líneas genéricas más sobresalientes de la literatura de este siglo: la contrautopía vinculada a la ciencia ficción. Género fuertemente codificado, al menos en sus paradigmáticas versiones, que conserva, si bien transformándolos sustancialmente, “todos los caracteres 'optimizantes' de la utopía, -en el sentido de imaginar una realidad en la cual lo que en la situación actual son sólo posibilidades se realiza llevando al extremo el cumplimiento de todas sus implicaciones"- para, al ofrecer imágenes de mundo "perfectamente negativas",

1 Véase Ludmer, "Territorios del present en la isla urbana". 
advertir sobre las consecuencias nefastas de la seducción por un pseudo progreso científico-tecnológico, autoritarismos de cualquier soporte ideológico, planificación racional y condicionamientos (Vattimo 95-112).

Más próxima a Pynchon, Burroughs y a Ballard, la literatura contrautópica de Cohen no conjetura sobre un mundo futuro perfectamente organizado en todos sus aspectos, optimizando hasta el límite las posibilidades del desarrollo científico-técnico, abre una hipótesis sobre el presente en clave anticipatoria ${ }^{2}$ donde a pesar de las limitaciones el prodigio tiene todavía lugar. ${ }^{3}$

Contra las versiones netamente apocalípticas que adoptan algunos cultores de la ciencia ficción, se advierte en la poética de Cohen cómo la confluencia de solidez y evanescencia con la que Marshal Berman caracterizó la experiencia de la modernidad puede asimilarse al paradigma del desorden o la complejidad -la base teórico-científica de su "realismo inseguro"-. En Todo lo sólido se desvanece en el aire, Berman señala que el hecho fundamental de la vida moderna, tal como lo experimenta Marx, es que ésta es radicalmente contradictoria en su base: capaz de todo menos de proporcionar estabilidad y solidez. En cada señal positiva que aparezca, inevitablemente se develará su contraparte caótica. Si se puede decir que la modernidad une a toda la humanidad, esta unidad es paradójica, es una unidad de la desunidad que lleva a la desintegración y la renovación perpetua, de lucha y contradicción, de ambigüedad y angustia. El rasgo más doloroso que el hombre moderno deberá enfrentar es la constante inestabilidad que tal sistema proporciona. Lo distintivo de las voces de Marx y de otros modernistas del

2 Véase Sarlo, “Una patria, una canción”.

3 Este contacto con algunos narradores de la llamada Nueva Ola -que se dio en los sesenta en los EE.UU. e Inglaterra cuando se confiere a la ciencia ficción un contenido filosófico y humanístico, se comienza a prestar mayor atención a las cualidades formales de esta modalidad narrativa y se hace de ella una suerte de neo-surrealismo- confirma que en líneas generales Cohen continúa la tradición que se ha reconocido como representativa de la ciencia ficción argentina: la conexión más directa con la ciencia ficción especulativa que subordina la tecnología y la imaginación científica para focalizar su interés en las emociones y actitudes humanas personales, así como en problemas sociales; una ciencia ficción más bien fantástica de transfondo filosófico, cuyos propios autores prefieren hacer hincapié en ese carácter fantástico de sus narraciones desdeñando el rótulo de ciencia ficción (Dellepiane; Capanna; Reati). De la Nueva Ola, destacamos, además, de importancia para la poética de Cohen, por una parte, la influencia en esta corriente de escritores modernistas; por otra, el vínculo de la ciencia ficción con la ficción paranoica -a través del desarrollo de imaginarios de amenaza y peligro, climas de complots conspirativos, construcciones delirantes y persecutorias-, y el consecuente desdibujamiento de los límites de la ciencia ficción, de la línea que separa a ésta del realismo; ya que este tipo de ciencia ficción realizaría discursivamente el dispositivo de amenaza desde su atención a la representación de la experiencia de las coacciones que sufre el sujeto en la sociedad contemporánea, producto del proceso histórico del desplazamiento del Estado de soberanía moderno a las sociedades de control, descriptas por Deleuze. Más que ofrecernos imágenes del futuro, se trata de "desfamiliarizar y reestructurar la experiencia que tenemos de nuestro propio presente [...] de transformar nuestro propio presente en el pasado determinado de lo que aún está por venir” (Jameson, "Progreso” 244).

Revista Iberoamericana, Vol. LXXX, Núm. 247, Abril-Junio 2014, $399-432$
ISSN 0034-9631 (Impreso) 
siglo xIX como Nietzsche y Baudelaire -quienes creían que los individuos modernos tenían la capacidad para comprender su destino y tras haberlo comprendido luchar contra él-es el cambio rápido y drástico de tonos e inflexiones, su disposición a volverse contra sí mismas, a cuestionar y negar todo lo que se ha dicho, a transformarse en una amplia gama de armonías y disonancias y a estirarse más allá de sus capacidades. A diferencia de ellos, los artistas y críticos del siglo xx caen en polarizaciones rígidas, generalizaciones categóricas, visiones cerradas. ${ }^{4}$

Las teorías del caos, podrían considerarse una concepción también dialéctica en tanto atentan contra la versión maquínico determinista del universo -según la cual, en base a modelos simples como el péndulo o las traslaciones planetarias, conociendo las condiciones iniciales se conocerán los resultados, y por tanto, no hay lugar para el azar porque todo está inexorablemente determinado por las leyes de la naturaleza-, para sostener que el mundo no es previsible, que los sistemas estables son la excepción frente a aquellos inestables, mezcla de caos y orden. El universo funciona de tal modo que del caos pueden nacer nuevas estructuras y es paradójicamente un estado de no equilibrio, el punto de partida que permite pasar del caos a la estructura estable. A diferencia del determinismo, las leyes de la naturaleza no están dadas, evolucionan como las especies; bifurcaciones, amplificaciones, fluctuaciones, modifican las leyes, haciendo del futuro pura incertidumbre, porque más allá de un cierto umbral de complejidad, los sistemas siguen rumbos imprevisibles, pierden sus condiciones iniciales y no se pueden revertir ni recuperar. Es Ilya Prigogine -cuyas investigaciones se centran en la termodinámica, la ciencia de la energía-, quien enfatiza la importancia de la dimensión temporal, la duración, en relación a sistemas abiertos, no simples o cerrados, aquellos alejados del equilibrio, es decir, conectados con el entorno con el que intercambian materia y energía y expuestos a la intervención de un elemento aleatorio, probabilístico. Cuando el flujo de energía se vuelve muy complejo produce grandes fluctuaciones en el interior del sistema. Tales fluctuaciones resultan en una reorganización del mismo en una estructura de mayor complejidad. Esto, a su vez, es la causa de nuevas fluctuaciones y por ende de mayor reorganización. Es la teoría de las llamadas estructuras disipativas, no sólo aplicables a las reacciones químicas, sino a los ecositemas o la conducta humana. Con ellas demuestra que la irreversibilidad de la segunda ley de la termodinámica no implica inexorablemente el máximo desorden final, la uniformidad o muerte del universo; la

4 En sentido semejante, se refiere Williams en The Country and the City al hecho de que la modernidad estética capta "las indisociables ambigüedades de la vida urbana moderna: sus liberaciones y disociaciones simultáneas, su extraña conjunción de aislamiento existencial e intensa proximidad y hasta solidaridad social. Mientras que Berman exalta la multifacética comprensión de la modernidad en Goethe, Marx y Baudelaire, los héroes de Williams son Blake, Wordsworth y Dickens autores conscientes de las contradicciones constitutivas de la disolución social en el proceso mismo de agregación en contraste con las visiones ulteriores más totalizadoras” (Pinkney 30-31).

Revista Iberoamericana, Vol. LXXX, Núm. 247, Abril-Junio 2014, 399-432
ISSN 0034-9631 (Impreso) 2154-4794 (Electrónico) 
flecha del tiempo tiene un papel constructivo: la creación de nuevos órdenes, nuevas estructuras espacio-temporales. (Prigogine La nueva; “Enfrentándose”; ¿ “El fin”) Parte de este vocabulario científico ingresa para constituir un símil del relato en "Como si empezáramos de nuevo”, el texto teórico que constituye una protosistematización de la poética de Cohen, donde el caos funciona especialmente como modelo de los modos de representación. ${ }^{6}$ Pero de este paradigma también se hallan rastros en la actitud asumida ante los derrumbes, finales, colapsos, ruinas y fracasos; los aludidos en algunos de sus textos no ficcionales como aquellos de los universos representados en sus textos narrativos, los del pasado y los del presente. ${ }^{7}$ De ahí que asociemos la dinámica no lineal a las ideas de Berman, porque ésta sería el sostén con el que el escritor intenta dar cuenta de la experiencia tardomoderna en términos también dialécticos, disonantes, esto es, como en los altos modernos, sin visiones negativas radicales o cerradas.

Tanto en sus textos críticos como en relatos y novelas Cohen alude a la sociedad posindustrial, el escenario objeto de reflexión y representación que impone nuevas acrobacias heroicas al artista, otros retos a una imaginación amenazada por la política y cultura del espectáculo, los mass media y sus simulacros, los relatos autoritarios y empobrecidos del entorno social. ${ }^{8}$

5 Véase Prigogine, “Enfrentándose con lo irracional” y “¿El fin de la ciencia?”; Prigogine y Stengers, $L a$ nueva alianza. Metamorfosis de la ciencia.

6 "Como si empezáramos de nuevo. Apuntes para un realismo inseguro", aparece en La vanguardia de Barcelona en 1984. En Argentina es publicado como “Apuntes para un realismo inseguro" en El cronista comercial (1993); luego, modificado levemente bajo el título “Como si empezáramos de nuevo”, el texto se publica en la revista Confines (1998); finalmente reaparece en el 2003 en el libro de ensayos Realmente fantástico y otros ensayos.

7 Algunos estudios que exploran los imaginarios apocalípticos en la literatura hispanoamericana contemporánea, suponen en algunos textos de Cohen, escenarios (pos) catástrofe, con índices de registro apocalíptico: un entendimiento de su contexto histórico y de los medios de narrarlo. "El apocalipsis es, en términos generales, un modo de aludir a otros problemas; de allí que las novelas (pos) catástrofe tiendan a subvertir el pacto mimético y a plantear la ficción como un lugar donde alegorizar (en el sentido que Avelar atribuye al término) el presente" (Fabry y Logie 17). En particular apuntan a identificar como elementos del mundo posapocalipticos, aquellos vinculados con la temporalidad: ruptura con el pasado y fin de todo proceso histórico, que es una ausencia de fin. Cfr. Oeyen, 257-267 y Steinberg 245-255.

8 Con la expresión sociedad posindustrial Cohen alude a los procesos del llamado capitalismo tardío (Jameson, Teoría). En los textos críticos de Cohen, se observan no pocas referencias a esta fase del capitalismo, aunque no se emplee el adjetivo tardío. (Véase "En opaco mediodía" [2001] o "Rigor y aventura” [2009]). En los textos literarios, a partir de El buitre en invierno (1985) se reconocen algunos de sus rasgos -en algunos casos, bajo la etiqueta "sociedad posindustrial”-, y, más adelante, según la versión neoliberal y globalizante que caracterizó la Argentina de los noventa (véase Pons, "Neoliberalismo” y Reati, Postales).

Revista Iberoamericana, Vol. LXXX, Núm. 247, Abril-Junio 2014, $399-432$
ISSN 0034-9631 (Impreso) 
En ese escenario caben también la disonancia, la inestabilidad, las líneas de fuga. ${ }^{9}$ Éstas se concretan en los textos ficcionales, cuando la lógica iterativa, uniforme, adormecedora, o de control del capitalismo tardío se rompe con la irrupción del acontecimiento; y en los textos teórico-críticos, con la noción de realismo propuesto, que, acorde a los nuevos modelos del universo, pretende derribar lo que se detenta como lógica determinista y reproductiva del realismo tradicional.

Agudizadas en el marco de la sociedad posindustrial, las tensiones, contradicciones y paradojas de los modernismos ${ }^{10}$ son retomadas a conciencia en un proyecto que exige un tipo de representación adecuado al horizonte de experiencias actuales -en el orden del conocimiento y de la praxis vital- y que liga la defensa de la autonomía a la rehabilitación del realismo, pero de una nueva especie.

A mediados de los ochenta, con la irrupción de las obras e intervenciones públicas de Guebel, Chitarroni, Caparrós, Sánchez, Chejfec, Cohen, entre otros, ${ }^{11}$ se produce una serie de polémicas en el campo literario argentino con respecto al status de la literatura y a sus vínculos con la política y la historia, y con respecto a la figura del escritor. Los llamados nuevos (Gramuglio), emergentes (De Diego), hiperliterarios (Avellaneda), lights o posmodernos (Catelli) o experimentalistas (Saitta) postulan posicionamientos, criterios de valoración, mediaciones con lo social, y modelos y medios de representación diferentes de los que dominaron en la literatura argentina hasta los primeros años de la

9 Suponemos aquí, siguiendo a Reynoso -quien considera las teorías de Prigogine como una manifestación de los modelos sistémicos cuyo objeto canónico son los sistemas complejos, caracterizados por la capacidad de autoorganizarse- que la complejidad no es en sentido estricto un atributo ontológico propio del fenómeno que se estudia, sino una escala inherente al punto de vista que se adopta y a los conceptos que se usan, en especial conceptos relacionales tales como el de interacción, organización y emergencia. De modo tal que, si bien los universos representados por Cohen son distópicos, por lo que en ellos se presentan extremados los rasgos negativos del presente y en consecuencia las contradicciones y paradojas que caracterizaron la modernidad llegan al límite, son mapeados por una teoría, con la que el sistema de la sociedad posindustrial es susceptible de una cierta y momentánea desestabilización y la impresión de una visión totalizadora, de este modo, se desarticula.

${ }^{10}$ Véase Berman, Todo lo sólido se desvanece en el aire, y Williams, La política del modernismo. Contra los nuevos conformistas.

${ }^{11}$ Algunos de estos escritores formaron parte del grupo Shangai -M. Caparrós, L. Chitarroni, J. Dorio, A. Pauls, S. Bizzio, S. Chejfec, D. Guebel. D. Bigongiari, R. Ibarlucía y D. Samoilovich- que luego dio forma a la revista Babel, en la que Cohen participa desde España con una sección a cargo -Batidore libero- destinada al comentario de textos. Babel, revista de libros que editó 22 números, desde abril de 1988 a marzo de 1991, bajo la dirección de Martín Caparrós y Jorge Dorio, concentra un movimiento de transformación de ciertas tendencias del pensamiento en el marco que va desde el fracaso del proyecto intelectual que se vinculó al democratismo alfonsinista hasta la "miseria de ideas" del neoliberalismo menemista. Los textos, autores, y concepciones de lo literario que circularon por la revista -un laboratorio de ideas de un denso caudal teórico y crítico que marcará una nueva redefinición de la tradición intelectual y literaria (Patiño)-, fueron centrales para el desarrollo de las ideas de Cohen sobre literatura.

\begin{tabular}{l} 
Revista Iberoamericana, Vol. LXXX, Núm. 247, Abril-Junio 2014, $399-432$ \\
\hline ISSN 0034-9631 (Impreso)
\end{tabular} 
década. Estos cambios reintroducen también discusiones sobre el realismo en términos distintos a los que dominaron las polémicas de los años anteriores. ${ }^{12}$

En general, estos escritores, rescatan a Fogwil, Aira, Lamborghini, Saer, Copi, y apuntan contra la literatura de los sesentas y setenta, que califican como la de "la época Roger Rabitt: cuando estaba claro que la ficción literaria estaba dispuesta a interactuar valientemente con la vida, a rectificarla, a revelarle la verdad, a encauzarla” (Caparrós 43). Negándole a la ficción la gran misión nacional, la identificación con los altos valores políticos, atacan el canon instalado de los realistas comprometidos, la narrativa más ligada a la narración clásica y la colección "Bibiloteca del Sur” de Editorial Planeta representada por O. Soriano, E. Galeano, A. Dal Masetto, T. Eloy Martínez, G. Saccomano, J. Forn, M. Figueras y R. Fresán. Observan en la literatura del momento una tendencia a la obscenidad o pornografía de la tortura y la desaparición que desentierra el pasado para vender la dictadura y convertirla en un hecho de mercado más. Las críticas efectuadas al status del compromiso en la literatura convergen en la identificación del realismo con estética del totalitarismo de mercado. Un realismo del dinero, del que más da, que se acomoda a todas las tendencias, como se adapta el capital a todas las necesidades. Este realismo de tipo mercantilista, incluye también a los textos vinculados al realismo sucio americano y a toda literatura no forjada en la experimentación, las teorías literarias, lo metaficcional y el exotismo, la desconfianza ante los grandes temas y las totalidades, el trabajo sobre el fragmento y la digresión, y la manipulación de los géneros. ${ }^{13}$

En una dirección semejante a la de los babélicos, la autonomía se rehabilita y mantiene en la poética de Cohen como el recurso más acabado que encontró el arte para distanciarse de las ficciones autoritarias, entre ellas el realismo. Cohen comparte la tendencia generalizada a identificar realismo con estética del mercado, estética promovida por la sociedad posindustrial, y señala también ingenuidades, límites, o prejuicios del viejo realismo: deficiencias propias de un hijo de la ilustración, con gestos de buena voluntad y política altruista, explotadas luego por la técnica y la empresa. ${ }^{14}$

12 Discusiones que en los años siguientes se trasladan al campo de la crítica, donde se destacan las siguientes intervenciones: el análisis del campo literario de la posdictadura, realizado por de Diego (2001), la publicación de El Imperio realista, coordinado por María Teresa Gramuglio para la Historia crítica de la literatura argentina, la lectura crítica que de éste último hace Dalmaroni (2002) y el intercambio producido en las Jornadas "Realismos" que tuvieron lugar en la Facultad de Humanidades y Artes de Rosario (diciembre de 2005), algunas de cuyas ponencias fueron luego publicadas en el Boletín/12 del Centro de Estudios de Teoría y crítica Literaria.

13 De todos modos, a pesar de ciertas proclamas hechas por estos autores y de las calificaciones recibidas por parte de la crítica, muchos de ellos, -Chejfec, Sánchez, Caparrós, Pauls, por ejemplo- entre los que se cuenta Cohen, han dado muestra, a través de resoluciones poéticas diferentes, de su interés por la historia argentina y por las consecuencias del accionar represivo del Estado durante los setenta. Para un desarrollo más detallado de esta cuestión véase Sassi "A pesar".

${ }^{14}$ En "En opaco mediodía”, un artículo del año 2001, Cohen reafirmaba la debilidad de un realismo comprometido, explotado por el sistema capitalista. "Uno de los mayores triunfos del capitalismo ha

Revista Iberoamericana, Vol. LXXX, Núm. 247, Abril-Junio 2014, $399-432$
ISSN 0034-9631 (Impreso) 
Contra el viejo y el nuevo realismo posindustrial, el "inseguro" o el "incierto" es una especie de realismo metonímico -en tanto presupone la contigüidad entre la materia y la mente, entre la experiencia y la invención, el realismo y lo fantástico-, en el que Cohen combinará la performatividad de la teoría de los actos de habla con ecos postestructuralistas y las teorías del caos. La narración realista incierta es un decir que implica una realización, un hacer múltiple: posibilita en el orden de la representación la irrupción de acontecimientos -no la mera concatenación de acciones-, y a la vez procura ser un acontecimiento para el lector, para el autor y para el mundo, de carácter imprevisible.

En el viraje hacia esta idea de realismo propuesta en sus textos no ficcionales a mediados de los ochenta, Cohen va consolidando una poética narrativa que se concretará en los relatos de la década del noventa -El fin de lo mismo, El testamento de O'Jaral, Inolvidables veladas y Hombres amables-, donde se observan diferentes y continuas referencias al fracaso y a la derrota.

Las novelas, tras la atención centrada en el presente de un país que ha sufrido importantes transformaciones debido a la profundización del modelo neoliberal y globalizador realizada durante los diez años de gobierno de Carlos Menem (1989-1999), exhiben en la propensión futurista distópica -en la hipérbole del fracaso presente-, un desvío hacia el pasado: un modo particular de registro de la caída del ideal revolucionario y de la derrota política, que significativamente ya se pronosticaban, en uno de sus

sido poner a los artistas al borde de la miseria para que, desde esa perspectiva, se hagan cargo de que existe la lucha de clases y terminen pensando que el arte puede servir a la revolución, la acusación, el mejoramiento de la sociedad o el triunfo de la causa de los que sufren: así los empujó el terreno de la servidumbre, cuando el arte debía proponerse un esclarecimiento mucho más radical; antes que nada, o aun como de paso, debería develar que el pensamiento utilitarista del capitalismo nos mata, no en pocos casos de tedio" (Cohen, "En opaco” 62). Pero debe también decirse, que más allá del equívoco de sus fines, el realismo también se rechaza tanto por sus presupuestos epistemológicos como por sus resultados en la construcción de la anécdota, cada vez más pobre en la solidez de una trama lineal; un realismo siempre "agobiado por el progreso del héroe hacia alguna realización” (Cohen, "La orfandad" 44). Refiriéndose al estado de la narración en la cultura posindustrial, Cohen da vueltas en torno a un lugar común -el fin de la narración y la pervivencia de la novela-. Lo que ha muerto con Proust es la novela, género ligado al mundo burgués y a un lector definido según ese mundo; otro género de narración que merecería otro nombre nace con Joyce, un género que la sociedad posindustrial ya no necesita. En ella predominan residuos novelísticos donde regreso de trama y realismo en el peor sentido conviven como remedos reproductivos de un género agotado que no es literatura y cuyo modelo son las series americanas sobre la vida privada de los abogados. La novela ha caído en una corrupción, en una exaltación tardía del cartesianismo que es habitualismo: un género en el cual la acción es inverosímilmente interior o exterior y el mundo y sus cosas un decorado, herramientas para el acabado más eficaz del argumento. El propósito de los cultores de ese género es contar una historia, la que a su vez debe ser eficaz en sojuzgar al lector (no convocarlo; atraparlo). A una propuesta así no es ajeno el ingreso de las ficciones en la esfera de la técnica y su rendición a las exigencias del público, que es el mercado. (Cohen, Realmente 140-141).

Revista Iberoamericana, Vol. LXXX, Núm. 247, Abril-Junio 2014, 399-432 ISSN 0034-9631 (Impreso) ISSN 2154-4794 (Electrónico) 
relatos primeros, escrito en Argentina antes del exilio, “El porvenir es más duro que el granito" (1975)..$^{15}$

En este sentido, su ficción primera se adelanta a las narrativas que en la década del noventa se focalizarán a través del duelo o la melancolía en el fin de las utopías sesentistas. Pero su producción madura-sostenida por una poética que desliga la noción de fracaso del continuo determinista para pensarlo desde el principio de incertidumbre del realismo inseguro-, si bien se aproxima a esas narrativas, guarda con ellas cierta distancia. Ya que las novelas de los años noventa, retoman el tema de la derrota política pero con trazas especiales, acordes a las normas preferenciales de la poética narrativa que Cohen consolida en esos años: la derrota es un resto que, aunque insistente, se rememora en forma desplazada, minimizada y desvinculada tanto del imperativo y los protocolos de la memoria o el testimonio, como de los índices de los procesos típicos de elaboración de las pérdidas.

En forma concomitante, algunos textos teórico/críticos escritos a fines de la década -esto es, cuando se perfilan más nítida y drásticamente las consecuencias de la inserción del modelo neoliberal en nuestro país-, registran algunas reflexiones sobre las relaciones entre fracaso y literatura. Allí, el contacto con un fracaso mayúsculo, exorbitado, no referido exclusivamente a los resultados del accionar terrorista del Estado en los setenta, sino a los de la civilización moderna de todo Occidente y propiciado por la contemplación de espacios latinoamericanos (Buenos Aires/Bogotá), puede considerarse un nuevo estímulo para el afianzamiento de una poética de la narrativa que va a transfigurar ese fracaso en umbral posible de creación y de cambio, de productividad. ${ }^{16}$

\section{UNA TEMPRANA CONFIGURACIÓN DE LA DERROTA}

"El porvenir es más duro que el granito" constituye una directa intervención en los debates en torno al papel del escritor en el proceso de politización generalizada de la cultura (Sarlo, Terán) que marcó los inicios de la década del setenta: una dramatización de la lucha interna del escritor, plagada de dudas y cuestionamientos, que exhibe la creciente desesperanza con respecto a la posibilidad de la revolución -representada en

${ }^{15}$ Lo que queda (1972) y Los pájaros también se comen (1975), -al que pertenece el cuento arriba citado-, fueron los dos primeros libros de cuentos publicados por Cohen en Buenos Aires. En la década del noventa se publican El oído absoluto (1989, 1997), El fin de lo mismo (1992), El testamento de O'Jaral (1994), Inolvidables veladas (1996), Hombres amables (1998, 2000). Sus textos posteriores son Los acuáticos (2001), La solución parcial (2003), Donde yo no estaba (2006), Impureza (2007).

${ }^{16}$ Con lo que se demuestra una vez más lo que ya hemos planteado en trabajos anteriores sobre el escritor: sus textos teórico críticos mantienen a la vez que una marcada coherencia y continuidad internas, una estrecha relación con sus textos ficcionales, constituyéndose un continuum, un pasaje por el que los primeros parecen funcionar como las normas preferenciales de los segundos.

\footnotetext{
Revista Iberoamericana, Vol. LXXX, Núm. 247, Abril-Junio 2014, 399-432 ISSN 0034-9631 (Impreso) ISSN 2154-4794 (Electrónico)
} 
el texto por una suma de metáforas que aluden a lo irrealizable, lo utópico, lo soterrado, lo invisible o lo innombrable: "el Nirvana”, "el continente mágico", "el gran pozo de los colores", "la Bastilla tomada y pintada de fondos marinos" que "se deja respirar pero no aparece" (72).

El cuento parece trasponer al tiempo de los hechos narrativos (mayo del 73), ${ }^{17} \mathrm{el}$ clima propio del tiempo de la escritura, más próximo que el de la acción narrativa al comienzo de la dictadura; un entretiempo-fines del 73/75- en el que la utopía sesentista cambia de rumbo, se desploman las inquietudes depositadas, desde la izquierda, en el gobierno peronista ${ }^{18}$ y se visualizan más fuertemente los rasgos con los que se han

17 Tiempo de la naciente primavera camporista, de sólo 49 días. Perón desde el exilio en España toma la decisión de que Cámpora fuera el candidato para Presidente de la Argentina por el peronismo, dado que por la proscripción él no podía presentarse. El armado apuntaba a que el próximo Presidente eliminara la proscripción, para que Perón pudiera retornar al país y luego de la renuncia, se llamaran a elecciones. El 11 de marzo de 1973, Argentina tuvo elecciones generales. Hector José Cámpora, gana con el 49.5\% de los votos, el líder radical, Ricardo Balbín, había salido segundo con un 21,3\%, y, como el FreJuLi no había obtenido más del $50 \%$ de los votos tenía que realizarse un ballotage entre la primera y segunda fuerza. Sin embargo, Balbín reconoció la victoria de Cámpora y renunció al ballotage. El delegado de Perón asumió el 25 de mayo de 1973, dándose así por finalizado el período dictatorial de la autoproclamada Revolución Argentina.

${ }^{18}$ La renuncia de Cámpora y de Solano Lima (11 de julio del 73) es precedida por la masacre de Ezeiza. El 20 de junio de 1973, cuando Perón regresa al país, la izquierda de Montoneros y el aparato de la derecha sindical de la CGT se enfrentaron por el control del palco de honor, con un saldo de 13 muertos y 365 heridos. El episodio preanuncia la serie de acontecimientos que signan la escalada creciente del ala derecha peronista y posibilitan la dictadura del 76. La asunción primera de Lastiri y la fórmula Perón/ Perón reaseguran el poder de López Rega (el 4 de agosto, en el Congreso Nacional Justicialista, ganaron los peronistas ortodoxos al consagrar a María Estela Martínez como compañera de su esposo en el binomio presidencial). A poco del impacto producido por la caída de Allende en Chile (11 de septiembre), se realizan los comicios que dan el triunfo a Perón. Éste asume la presidencia el 12 de octubre. El 1 de mayo de 1974, después de su discurso inaugurando el $99^{\circ}$ período legislativo, desde los balcones de la Casa Rosada, Perón echa de la plaza a la juventud peronista y montoneros -quienes con cánticos cuestionaban la presencia de gorilas en el gobierno-, diciendo: "El gobierno está empeñado en la liberación del país, no solamente del colonialismo, sino también de estos infiltrados que trabajan adentro y traidoramente son más peligrosos que los que trabajan afuera. Hoy resulta que algunos imberbes pretenden tener más mérito que los que lucharon durante veinte años”. A este explícito y público rechazo se suman algunos hechos institucionales, producidos bajo su gobierno, frente al copamiento del ERP en el Cuartel de Azul, la respuesta de Perón fue la reforma al código penal, la inducción a la renuncia de Oscar Bidegain gobernador de la provincia de Buenos Aires identificado con la Tendencia Revolucionaria del Peronismo, quien es sucedido por Calabró, vicegobernador y hombre de la Unión Obrera Metalúrgica de la derecha peronista. Por otra parte, el golpe, en Córdoba, del jefe de la policía provincial, coronel Antonio Navarro, quien desaloja, al gobernador y vicegobernador, Ricardo Obregón Cano y Atilio López, representantes del sector más progresista o de izquierda del peronismo. Uno histórico político, otro dirigente obrero identificado con la historia del Cordobazo. Mientras, la triple A (Alianza Anticomunista Argentina) que dirigía López Rega, estaba en plena acción. Su primer atentado registrado tuvo lugar el 21 de noviembre de 1973, cuando la organización -como represalia por el asesinato del sindicalista conservador José Ignacio Rucci a manos de los Montoneros un mes antes- colocó una bomba en el automóvil del senador

Revista Iberoamericana, Vol. LXXX, Núm. 247, Abril-Junio 2014, 399-432 ISSN 0034-9631 (Impreso) 
caracterizado los setenta-el desplazamiento del interés político, desde la transformación de la sociedad, hacia las estrategias de toma del poder, hacia la transformación del Estado, con la incorporación de una violencia ya naturalizada; las consecuentes primeras manifestaciones del terrorismo desde el Estado; la supresión casi total de las mediaciones entre el campo literario y el campo político-.$^{19}$

El cuento explora los conflictos de un escritor de izquierda, ${ }^{20}$ afectado por los acontecimientos que cruzan las esferas de lo público y lo privado -el ascenso del peronismo, la muerte de una compañera, la polaca-, poniendo en tensión tanto algunas de las controversias que la teoría del compromiso, dominante en los sesenta, implicó, ${ }^{21}$ como algunas de las referidas específicamente a la relación escritor/revolucionario, agudizadas a partir del 72 cuando una amplia franja de la izquierda debate sobre el ingreso a las filas del peronismo. Si bien puede considerarse, en general, como una variante conflictiva sobre las preguntas que caracterizaron el período -¿cómo seguir escribiendo sin abandonar la lucha? ¿cómo participar de la revolución sin abandonar el oficio? ¿cómo justificar la utilidad del oficio para la lucha revolucionaria?_²2 estas cuestiones resultan debilitadas y modificadas porque se tratan desde la perspectiva de un sujeto en estado melancólico.

Gerardo, es un ejemplo de conciencia desgarrada o culpable que se cuestiona sobre la posibilidad de ser un portavoz, un cronista del mundo, del país, de la gente, sobre su capacidad para asumir ese rol. Sin embargo, aunque el compromiso y la revolución sean el horizonte último, más que un conflicto de decisión entre escritura y directa acción política, más que el problema de la índole de los hechos a representar o de cómo escribirlos, traducirlos (realismo de tipo denuncialista/escritura experimental por ejemplo), lo que Gerardo se pregunta es si él, en su situación-de duelo patológico-puede llegar a representar algo y en ese caso, a qué proximidad o distancia de los hechos debe colocarse. Si el estar simplemente en los hechos, si participar, estar, ver "lo que pasa en la calle”, autoriza a representar sin haberse todavía compenetrado lo suficiente con

radical Hipólito Solari Yrigoyen. Para el inicio del Proceso de Reorganización Nacional, la Triple A ya había sido desmantelada, y las acciones represivas fueron llevadas a cabo en lo sucesivo, directamente desde el Estado.

19 Véase Diego, Quién de nosotros escribirá el Facundo. Intelectuales y escritores en la Argentina (19701986).

20 Marcelo Cohen fue en los setenta militante del PC (Saavedra). En otra entrevista, refiriéndose a sus comienzos de escritor y al efecto primero de la lectura de algunos escritores fantásticos, también reconoce: “Como las lecturas de los jóvenes izquierdistas de los '60 tendían al populismo, y yo además venía de una clase media donde el tono era bastante gris, la literatura fantástica abría otra lógica de la experiencia, de la mirada, quiero decir, el mundo podía ser de otra manera (Cohen en Speranza 75).

21 Esto es, si la participación activa en hechos de interés colectivo, si la participación política, concierne al hombre o concierne al escritor, afectando de diversas maneras, en este último caso, su tarea específica.

22 Véase Diego, Quién de nosotros.

Revista Iberoamericana, Vol. LXXX, Núm. 247, Abril-Junio 2014, $399-432$
ISSN 0034-9631 (Impreso)


el trabajo de las palabras, si para escribir no es necesario una consustanciación con el oficio y una cierta distancia crítica.

El cuento va a problematizar la teoría del compromiso, a través de una subjetividad escindida, que pone en jaque la relación directa, aproblemática entre individuo/sociedad, ya que la teoría del compromiso de Sartre que responde a la etapa de su primitivo existencialismo, supone la idea de individuo como ser auténtico, en cuanto a su relación con el universo. Según esa idea cada acto de cada quien modifica el conjunto universal, lo compromete y tiene, por lo mismo, un carácter moral a partir de sus efectos. El escritor, que hace público tal acontecimiento, debe ser consciente de lo que efectúa y saber cabalmente lo que está diciendo. Tal teoría se sostiene en una visión compacta del sujeto en tanto individuo, como una entidad que no puede dividirse. Su noción de sujeto es moral y jurídica, es el sujeto que responde ante la autoridad de los demás, que siempre lo amenazan con condenarlo al infierno, el infierno de la otredad. Un sujeto permanente, constante, idéntico a sí mismo, como el que registran los papeles de identidad y articulan las leyes civiles, ${ }^{23}$ ese infierno que para Sartre es la mirada del otro -en tanto que tiene la capacidad de observar y objetar al ego-, se presenta en el texto internalizado, a través de un proceso de identificación.

El comienzo de "El porvenir es más duro que el granito" es una taxativa negación sobre la que se vacilará durante todo el relato: "Un hombre no es representante del mundo; menos todavía si está loco, o alucinado, o enfermo de gripe y sacudido por una tos que más que tos es resentimiento" (Cohen, "El porvenir" 57). ${ }^{24}$ Ese es el estado, la convalecencia, en que Gerardo, llevado por un sentimiento del deber, recorrerá calles y calles de Buenos Aires, la noche anterior a la asunción de Cámpora al poder, el mismo día en que en un acto frente a la embajada de Chile, Allende pronunciara un discurso que, por su malestar, no pudo llegar a escuchar. ${ }^{25}$

A lo largo del relato, la narración del vagabundeo alterna con reflexiones sobre el papel del escritor como portavoz; sobre el deber estar allí y no quedar fuera del límite de las cosas, y el deber volver a su casa a aporrear las teclas. Pero la conciencia desgarrada, culpable del escritor está aquí fundamentalmente basada en la falta de la polaca, en el hecho de seguir viviendo, sin poder responder con alegría al llamado de los hechos, como hubiera respondido ella, su conciencia revolucionaria, o incluso, la revolución misma:

${ }^{23}$ Véase Matamoro, "Literatura y compromiso".

${ }^{24}$ Es un comienzo in extrema res que tiene su más rotunda palinodia en el siguiente pasaje: "Y probablemente esa noche él mismo, envuelto en el recuerdo de la polaca [...], él tosiendo y con más fiebre de la que podía permitirse para extender la caminata, declararía sin más trámite que sí, cualquier hombre alucinado y con el estómago vacío tenía derecho a declararse representante del país que explotaría al día siguiente [...]”(72).

${ }^{25}$ El ideal de la construcción de una patria socialista, se vio fortalecido por la presencia, en el acto de asunción presidencial, del presidente de Chile y del presidente de Cuba, Osvaldo Dorticós Torrado.

Revista Iberoamericana, Vol. LXXX, Núm. 247, Abril-Junio 2014, $399-432$
ISSN 0034-9631 (Impreso) 
Se había puesto el velador contra la cara repitiéndose que la Polaca lo habría empujado a vestirse, había encendido la radio, recorrido todas las estaciones y después la había apagado y se había quedado mirando la foto (la única que había en la pared), imaginando los ojos azules que miraban desde sus propios balcones, lanzando chispas como dos caleidoscopios llenos de algas, más reales que la dureza del papel. (59)

La falta de la polaca revelará falta en la subjetividad de Gerardo, quien exhibe algunos signos semejantes a los del trabajo melancólico. ${ }^{26}$ La polaca es una sombra que recae sobre él, lo persigue con su mirada mientras recorre las calles -la referencia a sus ojos es recurrente- hasta producirle, hacia el final del relato, un delirio de presencia, escenificación de una instancia crítica escindida del yo. La entrega incondicional al duelo poco deja para otros propósitos e intereses, deteriora el vínculo con el mundo, inhibe toda productividad y rompe, en definitiva, el compromiso con la orden de la realidad, provenga ésta tanto de los hechos que están ocurriendo como de la escritura. La pobreza y vaciedad del mundo coinciden con el empobrecimiento del yo, una rebaja en el sentimiento de sí, que se traduce en la falta de confianza para actuar y genera autorreproches, como el desconsuelo provocado por la imperdonable ausencia en el acto frente a la embajada de Chile; una pérdida en su yo que va a resultar reflejada en la figura de un bandoneonista. Su doble, "su imagen distorsionada, su esperpento o la dramatización fácil de su futuro” (57), es un fantasma musical. ${ }^{27}$ Cuando Gerardo decide volver a su casa para acostarse temprano se topa con un borracho, engominado y barbudo, que como él, tiene angustia y hambre. Con desesperación, el desconocido le exige que escuche su historia: el hombre antes bandoneonista en una orquesta importante, tuvo que dejar de tocar porque en una pelea, su adversario le cortó tres dedos con un cuchillo. Finalmente le pregunta a Gerardo, si va a haber algo distinto.

${ }^{26}$ El cuento traduce los rasgos típicos de la melancolía según la clásica formulación freudiana. La melancolía presentaría un síntoma que no está en el duelo: una pérdida de autoestima que se traduce en autorreproches dirigidos desde la conciencia moral. El trabajo de duelo, la comprensión gradual de que el objeto ya no existe, culmina cuando el yo queda liberado y sin inhibiciones, capaz ya de depositar la libido sobre un nuevo objeto, capaz de recactetizar el mundo. En la melancolía, la libido libre es retraída sobre el yo; se produce una identificación del yo con el objeto perdido y de esta manera los reproches del yo hacia ese objeto se convierten en autorreproches. La pérdida importante ha tenido lugar en el propio yo. En la base de este proceso hay una elección de objeto narcisista, es decir, el sujeto elige como objeto amoroso a uno que lo representa en algún sentido (Freud).

27 El texto parece desplegar aquí un fenómeno de introyección que según Freud, se conecta con la melancolía: cuando el sujeto hace pasar, en forma fantasmática, de "afuera" a "dentro" objetos y cualidades inherentes a estos objetos. El fantasma es una imaginaria escenificación en la que se halla presente el sujeto y que representa, en forma más o manos deformada por los procesos defensivos, la realización de un deseo, y, en último término, de un deseo inconciente. Según Freud, son ante todo los sueños diurnos, escenas, episodios, novelas, ficciones que el sujeto forja y se narra a sí mismo en estado de vigilia. En el fantasma, lo representado no es un objeto al cual tiende el sujeto, sino una secuencia de la que forma parte el propio sujeto y en la cual son posibles las permutaciones de papeles y de atribución.

Revista Iberoamericana, Vol. LXXX, Núm. 247, Abril-Junio 2014, $399-432$
ISSN 0034-9631 (Impreso) 
Gerardo cree que está refiriéndose a los acontecimientos políticos y le responde que no sabe. El músico, le dice entonces "-Y qué vas a saber. Vos tampoco estás contento. No podés saber. Lo que yo te preguntaba era si voy a poder tocar el bandoneón” (74). Como manera particular de tramitación del duelo por la polaca y por los ideales que representa, la construcción fantasmática hace que se reciba del otro, invertido, un mensaje propio -el bandoneonista es Gerardo preguntándose así mismo si podrá volver a escribir, preguntándose por su deseo-.

El vínculo del bandoneonista a través de la música con la realidad, tan exclusivo, tan profundo, tan directo, es algo que Gerardo aún debe aprender, con trabajo, para hacer de la escritura la única vía de conexión con el mundo. "La polaca se había muerto y los amigos estaban en sus cosas, y había que chocar contra el papel en blanco, más duro que el corazón de una bala, para tratar de responderse sin ayuda de nadie las preguntas que seguramente no iba a contestar mirando la caravana de coches envueltos en banderas que repetían Perón Perón que grande sos” (61). Es aquí donde se evidencian relaciones firmes con El oficio de poeta, la particular poética comprometida y la imagen de escritor, de Cesare Pavese a quien pertenece el epígrafe del cuento: “Apretar los dientes y sin una palabra darse de cabeza contra el porvenir, que te aseguro, es más duro que el granito”. Los conflictos de Pavese con la izquierda italiana, su defensa, más allá del compromiso del escritor con situaciones político/sociales, de una especificidad del arte, concebido como trabajo en situación de aislamiento, están sin duda presentes en esta especie de protopoética en un texto de comienzos de Cohen, en el que se delinea, tras los planteos de Gerardo, una posición de escritor que será desarrollada y enriquecida con otros aportes, más adelante.

Si bien la acción representada en El porvenir es más duro que el granito es anterior al comienzo del gobierno de Cámpora, el cuento presenta un clima de derrota anticipada, que se traduce en el ánimo del protagonista, dominado por el desconsuelo y una única certeza ante los próximos acontecimientos políticos: la permanencia solapada y al acecho, tras la primavera camporista, “de los milicos”.

\section{LA DERROTA EN EL PAISAJE POSINDUSTRIAL}

Desde mediados de los ochenta, cuando ya ha formulado la noción de "realismo inseguro", la narración es para Cohen la escritura del acontecimiento como acontecimiento, opacidad que resiste y actúa sobre lo real, trama de relatos como en Piglia o suma de ficciones autoritarias procuradas por la prensa, la publicidad e ideologías, lo que luego llamará "prosa de estado" ("Prosa”), el conglomerado de relatos dominantes sobre la realidad de un país, con valores de mentalidad pequeñoburguesa, que se infiltra en el sueño, la fantasía, la memoria; nubla y limita la percepción y avanza sobre la literatura, asimilándola y haciéndola funcional a sus principios.

\footnotetext{
Revista Iberoamericana, Vol. LXXX, Núm. 247, Abril-Junio 2014, 399-432 ISSN 0034-9631 (Impreso) 
En la Argentina, sus ingredientes básicos son los anacolutos del teatro político, las agudezas publicitarias, el show informativo y sus sermones, la mitología emotiva de series y telenovelas, la pedagogía cultural, pisicológica y espiritual de los suplementos de prensa, las jergas progresistas, juveniles y canallas parasitadas por los comunicadores, todo con incrustaciones españolas y doblajes centroamericanos. (Cohen, "Prosa” 1$)^{28}$

Una inflada doxa, compleja en su constitución, que excede todo aparato estatal, y cuya esfera de dominio amenaza o integra directamente la literatura a sus filas -haciendo de ella un remedo literario, de buenas formas, reducido a contenidos y personalismo-, obliga a redefinir cautelosamente elecciones y a extremar los gestos insumisos, rebeldes, anárquicos; gestos que implican sutiles desplazamientos, no la simple y obvia oposición hecha denuncia, -pasible de ser tragada por el sistema para mantenerse-, ni el intento de desactivarlo, escribiendo deliberadamente mal, al representar sin distancia, ni matices, estereotipos de usos vulgares de la lengua. ${ }^{29}$

Su poética se afirmará precisamente contra los principios que rigen esa prosa simplicidad, linealidad, transparencia, economía, pragmatismo, información, oposiciones binarias-, ${ }^{30}$ asumiendo, postergando, el vaticinio de Benjamin en "El narrador”: el inevitable final de una artesanía, el arte de narrar cuya materia prima devaluada es la experiencia.

Sin la inocencia del imperativo de originalidad, de cara a las determinaciones mismas de las consignas del lenguaje y a una cultura que exhuda saturación, Cohen postulará como materia prima de la narración, como primera experiencia ofrecida, un contacto artesanal con la palabra, que al impulsar relaciones desmedidas para hacer tajos a la doxa, supera el en sí de lo sucedido y recobra espacio, tiempo, cuerpo y desgaste -los

\footnotetext{
${ }^{28}$ Antes de precisar y desarrollar la noción "prosa de estado” (2006), Cohen, en el mismo trabajo en que postula su noción de realismo inseguro, ya se había referido a la idea de una doxa creciente, falaz y represiva: “Tanto se puede decir nuestras fantasías nos dominan, como, menos psicológicamente, el lenguaje constituye la realidad. Salvo casos de presciencia, estableció Kant, los humanos perciben las cosas mediadas por categorías mentales. Lo que los taoístas no podían prever era que la sutil membrana mediadora iba a volverse mucho más gruesa y opaca. A las deficiencias de los sentidos y la estructura de la conciencia, a los velos del deseo, a los mitos fundacionales y fundamentales, a las ficciones científicas y periodísticas, la civilización tecnológica añadió un perpetuo rumor de mensajes, un repertorio de eslóganes y un sinfín de imágenes que nos envuelven en un simulacro más o menos variable, una secreción subsidiaria del pensamiento que se llama excluyentemente, "la realidad” (Cohen, "Como si” 130).

${ }^{29}$ Cohen se refiere a la "mala escritura" o "infraliteratura", cuyos representantes respetables reconoce en Aira, o Zelarayán, sin dejar de subrayar el peligro que supone: "Menos interesante es que la perversión pase, por escasez de recursos o indolencia, a avalarse en el referente, por ejemplo en taxonomías sexuales que engalanan la tele o se ofrecen en Internet, o en el elogio de la vida amoral, a modo de distinción retributiva del pelagatos" (Cohen, "Prosa” 6). Sobre los riesgos de la mala escritura, insistirá, más adelante, en "Rigor y Aventura".

${ }^{30}$ Véase Sánchez, “'Iniciar por fin el éxodo’”.
}

Revista Iberoamericana, Vol. LXXX, Núm. 247, Abril-Junio 2014, 399-432
ISSN 2154-4794 (Electrónico)


aspectos obliterados por el lenguaje representativo-. Analogías, imágenes potentes, excursos, tiempos muertos, para quebrar el excesivo anclaje referencial, distraer el discurso hegemónico que subyace a una anécdota demasiado sólida, y enfatizar el derroche, el exceso, la dispersión, una antieconomía de la prosa. ${ }^{31}$

Surcada por los mass media y las contradicciones del progreso, la iconografía de la ciudad posindustrial que Cohen desarrolla en los relatos de los noventa, con basurales tecnológicos, pantallas televisivas gigantescas, psicofármacos, anonimia del poder, tribus urbanas, grupos iconoclastas, tiene su paradigma en la imagen de una cárcel que recuerda el Panóptico programado por Bentham: la prisión con torre central, desde la que un ojo omnisciente vigila. Una cárcel marina, donde los individuos sometidos al control y la repetición, deliberan barruntando hipótesis sobre su origen y su sentido. ${ }^{32}$ Sobre ese paisaje donde se suplanta la comunicación por la textualidad informativa y donde los medios constituyen la única experiencia simulacro, se narra, en el límite, la posibilidad todavía del prodigio. Lo maravilloso y lejano que cuenta esta narración, es lo que en términos de Benjamin le da cuerpo: la experiencia. Pues si bien estos relatos exhiben el triunfo de la tendencia que denunciaba Benjamin cuando confirma la extinción de la experiencia, en el verosímil instalado de la ciencia ficción, la experiencia asoma como posibilidad que linda con lo fantástico. "Sabes Frankie me pasó una cosa”, así en el asombro, la confusión, la extrañeza, se cierra el relato "La ilusión monarca" de El fin de lo mismo (1992); esa constatación y esas sensaciones es lo que muestran la mayor parte de los personajes, después de largos recorridos de carácter épico, sacudidos por acontecimientos cuya íntima naturaleza y su sentido quedan a medias revelados: ocultos, inaccesibles, innominados, travestidos por el humor, trasmutados por el lirismo, o confundidos en la mezcla de lenguajes.

Estos textos se inscriben en la tendencia general reconocida por la crítica para la narrativa argentina de la época: el desplazamiento del interés desde la historia y la interpretación sobre el pasado reciente característico de los años ochenta, hacia el presente, "no como enigma a resolver sino como escenario a representar", pero a través de torsiones desrealizadoras (Sarlo, "La novela” 473), modos de representación alejados de los procedimientos realistas, ${ }^{33}$ hipótesis del fantasy o modos sesgados o laterales de la ciencia ficción contemporánea. ${ }^{34}$

De todos modos, El testamento de O'Jaral, Inolvidables veladas y Hombres amables, son textos en los que pueden leerse condensaciones o síntesis históricas, ya que si bien constituyen relatos de anticipación en clave de crítica al neoliberalismo y

${ }^{31}$ Estas ideas fueron publicadas en Chiani “La fiesta”. Son también retomadas y desarrolladas por Silvina Sánchez, en un trabajo inédito (Sánchez, "Iniciar”).

32 Véase Cohen, "La ilusión monarca”.

${ }^{33}$ Véase Saítta, "La narración de la pobreza en la literatura argentina del siglo XX".

34 Véase Berg, "Los relatos de la ciudad: papeles de trabajo".

ISSN 0034-9631 (Impreso) 
la globalización imperantes en el tiempo de su escritura, ${ }^{35}$ no dejan de hacer referencia a la dictadura y a la lucha armada de los setenta en Argentina, ofreciendo en algunos casos, versiones y balances de la derrota.

Ya El oído absoluto -publicada en 1989 y reeditada en 1997-, adosa al escenario contrautópico de la isla Lorelei-reino del kitsch posmoderno y de la política espectáculo, dominado por el entretenimiento, el consumo, la basura material y simbólica, donde proliferan como agentes de homogeneización ideológico-imaginaria eslóganes, propagandas, noticias y las banales canciones de su creador, Silvio Fulvio Campomanesuna escena de rapto, violencia y tortura que remite directamente a los años de la guerra sucia en nuestro país. ${ }^{36}$

Pero es quizás El testamento de O’ Jaral (1995), donde esa síntesis histórica alcanza mayor despliegue porque se vincula directamente al desarrollo de la trama. Allí, aunque las referencias a la derrota se concentran en torno a un único personaje, el Galgo Ravinkel, y se desarrollan sólo en dos tramos de la novela, un racconto y un diálogo, se convierten en motivación de la acción novelesca. Ésta comienza con la solicitud al traductor O'Jaral, por parte de dos emisarios de los de Arriba, que detentan el poder, para que dé con el líder oculto de un grupo disidente -formado "en general por pobres emergentes y profesionales divorciados del consumo” (144)-, quien organiza acciones erráticas, sin objetivos precisos. La narración muestra los avatares del trayecto que realiza el traductor para encontrar al ideólogo de los rebeldes, el Galgo Ravinkel, su hermanastro, al que no ve desde dieciocho años atrás debido precisamente a su desacuerdo con el tipo de prácticas políticas impulsadas por el Galgo en el pasado:

[... ] un día el Galgo entró en un grupo clandestino. Al fin y al cabo era un judío laico, y languidecía por encontrar un dios de aspecto secular. Por eso encabezó una fracción en el grupo y fundó otro; así cuatro veces hasta que se dejó reclutar, con rango de dirigente, por una organización insurreccional poderosa. Alquiló un departamentito y se llevó a vivir con él a O’Jaral [...] Los dobles fondos de los armarios se llenaron de granadas, dinero, pasquines, instrumental médico. Los primeros disparos, la primera sangre salida del cuerpo humano despertaron en O'Jaral menos miedo que escepticismo repugnado. No lo impresionaba la muerte; no entendía bien que quería decir. Si algo lo irritaba del ideario del Galgo era que para ejercer el odio contra unos necesitara persuadirse de su amor por otros; o viceversa. En la revolución que pregonaba el grupo, y hasta en un detallado programa social, O’Jaral veía un exceso de inarmonía, de mescolanza e impureza. No toleraba que un mero aliado, sin pedir permiso, se convirtiera de golpe en compañero o amigo. Todo compromiso podía volverse lastre; eso pensaba. Y que él, O’Jaral, aún tenía que organizarse a sí mismo [... ] algunos meses después O’Jaral iba a enterarse de que el Cuerpo Interamericano de Seguridad había neutralizado, mediante

\footnotetext{
${ }^{35}$ Véase Pons, "Neoliberalismo y producción cultural” y Reati, Postales del porvenir.

${ }^{36}$ Véase Amar Sánchez, Instrucciones para la derrota.
}

Revista Iberoamericana, Vol. LXXX, Núm. 247, Abril-Junio 2014, 399-432
ISSN 2154-4794 (Electrónico)


exterminio sobre todo, al grupo subversivo donde militaba el Galgo y a una docena de grupos más, aparte de supuestas redes de insumisión civil. (24)

Con este racconto se incorporan a la novela discursos ideológicos, políticos y sociales residuales de los setenta en contrastación con el mundo de poderes "globalizadores" de control contrautópico que delinea la ficción. Pero si bien "las consignas y prácticas políticas de los grupos subterráneos (por ejemplo la consigna: "La política es la existencia”), se muestran como continuidades memorísticas e identitarias del pasado que siguen latentes y en acción en un presente que pretende anularlos” (Braccamonte 7), éstas se discuten desde la perspectiva del protagonista, son debatidas en el diálogo donde O’Jaral desaprueba especialmente la irresponsabilidad de los dirigentes con respecto a los jóvenes y la inviabilidad de ese proyecto que nada nuevo ofrece a un presente donde la democracia concentracionaria, la inexistencia del estado y el principio económico/tecnológico impuesto por los consorcios aúna a la máxima pobreza, la repetición de lo mismo.

¡Ahí afuera (señala la ventana con la cabeza) hay gente que te sigue, Ravinkel! Jóvenes y maduros creyendo que te siguen hacia, hacia [... . Ofrecés algo que se finge desconocido pero será lo mismo de siempre. Y te ocultas para que lo que ofrecés parezca más desconocido todavía. Y decenas de personas se precipitan detrás de tus vaguedades en el caos, que podría ser creativo pero los llevará a la misma cuadrícula donde se mueven ahora. Vino viejo en odres restaurados. El mismo perro con otro collar. Ravinkel, el oscuro ¡Flor de fábula! Seguís matando y mandando a morir. (158-159)

Y en este caso, además, se traducen ficcionalmente en los argumentos de O’Jaral -comprobándose la estrecha relación que la producción narrativa de Cohen mantiene con sus textos teórico-críticos- nociones de las teorías del caos.

Tu idea de la relación caos-orden es que es reversible. Vos lo dijiste: el tiempo no pasa [...] Sin embargo, tengo que darte una noticia: el tiempo tiene una dirección. Los procesos se bifurcan, se hacen cada vez más complejos, se aceleran porque todos, en todo momento, estamos trabajando para cambiar las condiciones, y como todos los elementos de un sistema son relevantes, la totalidad es lógicamente imprevisible. Pero esto no quiere decir que no haya una dirección. Hacia algún lado vamos, aunque ignorarlo lastime tu idolatría [...] Por lo pronto todo conflicto crea formas, pero no vuelve a las formas anteriores. Ergo hay una flecha del tiempo. (156)

Inolvidables Veladas de 1996, se escribe en los años en que se registra el llamado renacimiento del tango, fenómeno que surge aproximadamente a mediados de la década del ochenta y cuya explosión se produce a mediados de la década siguiente. Esta explosión coincide con el período de mayor anclaje del neoliberalismo en nuestro

Revista Iberoamericana, Vol. LXXX, Núm. 247, Abril-Junio 2014, $399-432$
ISSN 2154-4794 (Electrónico) 
país, y el consecuente vaciamiento de contenido de los relatos sobre la nación. La venta de los activos del Estado y la concesión de los recursos nacionales, corren paralelos a la circulación del discurso sobre lo privado en contraposición a lo estatal que pasa a calificarse como deficiente, y del discurso sobre la globalización, utilizado por parte de los grupos hegemónicos para justificar cualquier tipo de práctica económica.

En Inolvidables Veladas, Argentina se reduce al país del barrio del tango y el negocio/espectáculo del tango, género hegemónico que obliga a replegarse al resto de las manifestaciones musicales, volviéndolas prácticamente inexistentes, aparece como la consecuencia de la desaparición de los modos históricos en que se construía la identidad argentina: el tango es el sistema, el relato, el mito de origen planificado, en términos de mercancía renovada, impuesto por organismos multinacionales donde lo argentino se cataliza -fenómeno metaforizado en el texto en un proceso gástrico de carácter masturbatorio-, ante la ausencia de un proyecto de nación integrador, en términos políticos y económicos. Es sobre el uso ideológico del tango como discurso identificatorio -“música típica, nuestra”- ante el vacío abierto por la globalización capitalista, que reflexiona críticamente la novela en relación al problema de la identidad individual. Golo, el protagonista, hijo de una cantante de tangos eternizada en un holograma, desde su niñez, por un contrato firmado junto a su madre, está obligado a cumplir con las iniciativas socio-culturales del consorcio Senthuria y sufre el acecho interesado tanto de sus representantes como de la gente, que esperan de él la manifestación de “algo” para renovar la mitología tanguera y dar cohesión representativa a la comunidad. Convertido en “efigie popular”, se pregunta a sí mismo -vacío tapado por las definiciones de los otros- sobre la autenticidad y el origen de su destino de tango, y está también a la espera de que algo surja en él.

En este contexto, breves alusiones a la derrota histórica parecen refractarse en los frustrados intentos de Golo en su juventud para huir de las presiones del Consorcio: "Se había fugado. Típicamente, había ingresado en grupos clandestinos iconoclastas, después viajado por zonas rurales recogiendo la uva o la naranja, y más tarde, en un ranchito de un valle minero, se había amancebado con una chica mestiza y bajado al socavón en madrugadas" (43). Un arranque de "rebeldía extremista” que termina en el regreso a la ciudad y cuyas enseñanzas, vinculadas a prácticas subversivas -“Golo guardaba la noción de que los rebeldes debían insertarse cuando pudieran en el aparato de los poderosos y utilizarlo solapadamente para fines propios” (51)-, son igualmente infructuosas.

En Hombres amables (1998), texto en el que se conectan ciencia ficción, heroísmo y reflexión sobre las posibilidades del relato en la sociedad tardoindustrial, Cohen va a extremar el característico ascetismo de sus ficciones anticipativas, para acentuar la miseria material y simbólica de los marginales o caídos del sistema: traficantes de fármacos y de sal; multitud de niños flacos vendiendo cosas robadas; buraqueros, habitantes de la villa de los pozos; los sincasa, profanadores de tumbas; los Velados y los Lucidos,

Revista Iberoamericana, Vol. LXXX, Núm. 247, Abril-Junio 2014, $399-432$
ISSN 0034-9631 (Impreso) 
dos bandas con idearios antagónicos, hechos de restos y caprichos; indias; jóvenes en blanco, perdidos. Lejos, sin afectarlos, el mundo de las decisiones, representado por los consorcios. ${ }^{37}$

El paisaje social de un barrio periférico, en ruinas y a la intemperie: como sus pobladores, "área de estupor, vástago que la época dejó caer" (166). Su identidad se cifra en el baldío, un basural, proyecto abortado de un polígono de industrias militares. Más allá un cementerio, un camposanto de coches y el "inestable pacto entre el arrabal y el campo" (151).

Cohen diseña un barrio tensionado hacia el afuera, hacia el vacío, sin la fuerza contenedora del centro urbano. Si antes ya había desdibujado los límites de la nación, ahora la nitidez de la cuadrícula urbana y con ella las formas de cohesión social, toda posible comunidad. En Hombres amables el espacio físico y el social coinciden: desmoronamiento de los lazos sociales, defección de antiguas prácticas e instituciones garantes de sociabilidad, que sobreviven en el café Salcedo "tan triste por fuera como inhóspito por dentro" o en el Bailable Salpicca donde Manisito Vango, inventor de un ritmo perturbador, el gurubel, sacude una masa móvil de gestos autárquicos.

Sentado sobre un taburete en el montículo de basura, con estos materiales, Emilio Dainez, el protagonista, intenta construir una zona, "una forma neutra, tolerante, una forma que contenga el caos sin disimularlo. Que no engañe sobre el frío de la intemperie, que no niegue lo muy abajo que estamos". "Yo quiero una forma inteligente para nuestra pobreza” (207) dice este hijo de los sesenta, matemático, profesor y revolucionario, otro caído que ahora trabaja para Senthuria -escribe números primos que le sirven al consorcio para violar códigos de correos electrónicos privados-.

En Hombres amables se narra un acto de creación, a partir de requechos, y desde el margen, alternando una tercera persona narrativa con las voces de un círculo de cófrades formado por la hija de Dainez y sus amigas. Con algo de sesión espiritista, no obstante la miseria de su lenguaje, esta especie de coro degradado proyecta la historia de Dainez -tanto los hechos anteriores a la miseria presente como los que son objeto del relato- a una dimensión mítico-heroica. La repite una y otra vez porque no entiende demasiado ni sus acciones ni los pensamientos que dejó grabados y porque se han terminado los hechos legendarios. El presente de su enunciación es un presente ya vacío de leyenda. El coro convierte la vida de Dainez en la última leyenda, trayectoria de pruebas de un héroe, santo o mártir, protagonista de sucesos maravillosos y portador de un mensaje críptico.

Es en este marco legendario, y a través de la voz coral, donde se inscribe como prólogo, como prehistoria del trayecto heroico, la derrota previa de Dainez:

${ }^{37}$ Aquí, otra vez como en Inolvidables Veladas, el consorcio "Senthuria" reaparece como ícono de la concentración monstruosa de capital, propia de los noventa, a través del manejo de negocios múltiples -industrias, letras, espectáculos-. En este caso, el negocio es la información.

\footnotetext{
Revista Iberoamericana, Vol. LXXX, Núm. 247, Abril-Junio 2014, 399-432 ISSN 0034-9631 (Impreso) ISSN 2154-4794 (Electrónico)
} 
Dainez, mi papá era un gran matemático, un científico que enseñaba en un colegio. ¿Por qué?

Ya lo sabés. Por amor y porque sí. Él era un científico para todo, para la ciencia y la cultura, un hombre de ideas, un rebelde. Más anterior había sido revolucionario militantte comprometido. Con mi madre. Pero los caprichos de la vida cambiaban y en ese entonces ya era nomás rebelde, lo otro no servía [...] Y buen, pero un día ocurre esto: que cierran el colegio donde Dainez es profesor. Huelga, pocos quieren hacer, casi todos se van vencidos a sus casas, y entonces Dainez empezó a protestar que la época es una catástrofe, que unos aniquilan la educación y a otros la educación les resbala, y diciendo que se han perdido los ideales, bla, bla [...] Y Dainez gritaba: Nos están revolviendo el puñal en la herida. Nos desangramos y nadie se escandaliza. ¿Y la justicia, decía? Derrota. Traidores. Entretanto otros profesores organizaban encuestas para productos del hogar, y otros también estaban en la miseria pero no chillaban En cambio mi papá chillaba como si fuera el único. Le chillaba a mi mamá. A mí, sin ir más lejos. $[\ldots]$

Dainez viéndome por ahí entre los guasos, decía: barrios feos, desempleo, miseria, corrupción. Maldad social, gritaba. Maldad, maldad. Gritaba bajito, como maullando. Decía: última peripecia de la explotación; los intelectuales se vuelven hipócritas, los pobres se vuelven malos [...] Y entonces a él le dio ese ataque. Y ahí viene el final del Prólogo: la depresión de Dainez. (162-164)

En las tres novelas, el ideal revolucionario, el compromiso, la lucha, la derrota, se encuadran en microhistorias que corresponden al pasado de los personajes y que contrastan con un presente de jóvenes empobrecidos y despolitizados, a quienes "a fuerza de encarnarse en frases prestadas, siempre las mismas, se les han agotado unos sentimientos que tampoco podían ser suyos. Y ahora están en blanco" (170).

La reinserción de ese pasado histórico, en el marco de la ciencia ficción sociopolítica de Cohen, que apunta fundamentalmente a extremar las consecuencias negativas de los procesos socioculturales característicos del neoliberalismo y la globalización, no se lee sin embargo, simple y unidireccionalmente como continuidad de una alternativa legítima para contrarrestar esas consecuencias, o como rastros persistentes de un duelo sin resolución.

Los sobrevivientes, más o menos tocados por la derrota según los casos, lejos de ser vencidos por la desilusión, sentimientos apocalípticos, la ira, o insistir en la lógica reproductiva de la memoria, intentan con obstáculos, esfuerzos e incluso nuevas derrotas, -el hambre, el desamparo, el embrutecimiento-, en esos escenarios corroídos, descubrir o crear nuevas zonas de intercambio y de productividad humana y social. Representan también los esfuerzos y obstáculos a los que se enfrenta una literatura que si no deja de remitir al pasado, lo recrea y critica en sus aristas controvertidas sin rendirle culto, y obtiene del presente las claves de una poética no resuelta en los moldes genérico/ estéticos a los que suelen empalmarse los intereses sociopolíticos que recobraron fuerza

Revista Iberoamericana, Vol. LXXX, Núm. 247, Abril-Junio 2014, $399-432$
ISSN 0034-9631 (Impreso) 
en la literatura latinoamericana de los noventa (realismo, testimonio, novela histórica, nuevos formatos del policial, etc).

\section{Alegoría y “REALISMO INSEgURO”: EL FRACASO EN LOS TEXTOS TEÓRICO/CRÍTICOS}

Cuando Martín Caparrós intenta determinar algunos rasgos de la narrativa de "los nuevos” -entre los que incluye, a Marcelo Cohen junto a Guebel, Chejfec, Chitarroni y Pauls-, sitúa en el fracaso, en el vacío, la condición espacio/epocal de escritura, que identifica con el desierto:

Suena risible: en mi mirada, Buenos Aires 1980 volvió a ser un desierto, como lo fue la Argentina en 1880. A mediados del siglo pasado, Sarmiento lanzó la cuidadosa construcción de la Argentina como desierto. El Facundo, ese primer gran texto, edificó la conciencia del vacío; el país era un territorio desocupado a fuerza de estar ocupado por gauchos, indios y otros inconvenientes. La Argentina como mala parodia de Arabia. [...] Ahora, ante mis ojos, la idea de otro desierto creado a fuerza de destrucción, y del fracaso de aquellas construcciones. Esta indefinible impresión de encontrarse frente a una tierra incógnita, blanco en la presuntuosidad de los mapas, una suerte de ni siquiera selva virgen. $\mathrm{O}$, tal vez, virgen por exceso, porque ya no hay cómo excitarla. Y entonces la actitud de refundar, la idea de que hay que empezar una vez más pero sin la alegría y la confianza fundacionales. Empezar una vez más, pero sabiendo que empezar puede no servir para nada, una vez más. (Caparrós 44) ${ }^{38}$

Casi diez años después Cohen escribe “La ciencia ficción y los restos del porvenir”: el vacío aquí es el riachuelo el puerto, el río; otra imagen sarmientina que en Facundo constituía precisamente la contracara del desierto: la civilización y el progreso.

${ }^{38}$ Las impresiones de este pasaje del trabajo de Caparrós remiten al descorazonado clima de la época, provocado por los acontecimientos producidos durante el último período del gobierno de Ricardo Alfonsín: sequías que afectaron las cosechas y la provisión de energía; el copamiento al Regimiento 3 de Infantería de La Tablada, llevado a cabo por miembros del Movimiento "Todos por la Patria”, con un saldo de 39 muertos y explicaciones turbias sobre los móviles y sobre la forma en que fue resuelta la cuestión; el alza incontrolada de las tasas de interés y el agotamiento de las reservas del Banco Central para intentar mantener el valor de un austral que se depreciaba cada vez más frente al dólar; el golpe de mercado producido por los principales grupos económicos al retirar sus depósitos de los bancos, retener divisas producidas por exportaciones y demorar el pago de impuestos. Una situación que se tornaba cada vez menos manejable con hiperinflación, pérdida del poder adquisitivo de los salarios, remarcación de precios, compra compulsiva de dólares por parte de los especuladores y saqueos a supermercados que empiezan a producirse en el Gran Buenos Aires, Rosario y otras ciudades. En ese marco, Alfonsín anuncia que está dispuesto a resignar la primera magistratura. Gesto que se concreta el 30 de junio, después de febriles negociaciones entre los delegados del presidente y del mandatario electo, Carlos Menem.

Revista Iberoamericana, Vol. LXXX, Núm. 247, Abril-Junio 2014, 399-432 ISSN 0034-9631 (Impreso) ISSN 2154-4794 (Electrónico) 
Publicado en las vísperas del nuevo milenio y dedicado a la ciencia ficción, "La ciencia ficción y los restos del porvenir" comienza con la imagen del Riachuelo porteño, especie de alegoría en el sentido que Benjamin (1991) adjudicó a la versión alegórica barroca: muestra de la naturaleza mortificada, historia representada como paisaje primordial petrificado, suspendida y contemplada en la cristalización de sus ruinas. ${ }^{39}$

Aquí también el riachuelo se presenta como un fragmento ruinoso que se despliega para poner de manifiesto la certeza de una sensación: el fracaso; un paisaje que va a impulsar la reflexión crítica hacia un doble frente: pasado y futuro, tanto de la cultura humana en general, de la civilización occidental, como de la literatura y la ciencia ficción. La superposición de tiempos-anticipada en el pasado/futuro del título del artículo: restos/ porvenir-, esa amalgama temporal contenida en la imagen del riachuelo, es lo que permite conjeturar que la alegoría con la que Cohen inicia la reflexión sobre el desarrollo y las posibilidades del género de anticipación, sufre un proceso de transvaloración. Porque a diferencia de la alegoría barroca que implica una concepción de la historia decadente y negativa en la cual no existe la redención y todo tiende a la destrucción, la visión de la historia que anida en el riachuelo es más bien caótica, lo que abre cauce a la posibilidad de imaginar un futuro, capaz de ser reinventado por el arte, como se anticipa en la tenaz pervivencia de las islas flotantes de los camalotes entre los desechos del riachuelo; es en ellos donde se detiene primero la mirada que los personifica.

\begin{abstract}
Una tenacidad comunitaria los llevó a colarse en los diques y las esclusas, pero sobre todo a agruparse en el riachuelo, de modo que entre una orilla y otra cualquier artefacto humano quedó sitiado por vastos, chatos, islotes de vegetación que se mecían apenas, igual de sólidos a la vista que inservibles para caminar. El hecho de que sólo trabajaran para sí mismos realzaba la violencia del compromiso. (Cohen 156)
\end{abstract}

No es casual que este artículo comience con la descripción de un paisaje, ya que en la narrativa de Cohen, los espacios - en gran parte de sus textos, marginales, híbridos, de mezcla-, son el doble, el reverso, de los personajes y sus conciencias: "La relación es dialéctica. Somos el paisaje y el paisaje es lo que hemos hecho de él y viceversa" (Cohen, "La novela" 5). Y para el paisaje ruinoso y su conciencia, hay siempre una brecha, un camalote que continúa su trabajo, una imaginación que resiste, se sobrepone al fracaso y construye con él, hay "restos del porvenir".

Este trabajo, en sus movimientos, en sus bloques descriptivos/argumentativos, exhibe un trazado que parece delinear la génesis y desarrollo de su poética, la cual, si nace de una aguda percepción del paisaje posindustrial, de sus desechos y fracasos, no

39 "La ciencia ficción y los restos del porvenir" fue publicado inicialmente en 1999 y luego incluido en Realmente fantástico y otros ensayos (2003).

Revista Iberoamericana, Vol. LXXX, Núm. 247, Abril-Junio 2014, 399-432
ISSN 2154-4794 (Electrónico) 
recae en visiones totalmente apocalípticas, y, sin ironía, ni cinismo, sigue confiando en la complejidad caótica de la vida y de la literatura.

\begin{abstract}
Desde la devastada ribera del barrio de la Boca, el paisaje del Riachuelo era el reverso de la agitada mente colectiva porteña: un umbral mortecino en donde la ciudad, que en otro tiempo creció en la fantasía de la posibilidad ilimitada, se continuaba con el depósito de lo que su deseo había proscripto o evacuado. Tapando casi el agua negroide, grumosa de desechos industriales, los camalotes relucían como joyas de plástico entre tufos de herrumbre y de curtiembre. Se oía casi el rumor de las bacterias sintetizando carbono, vano paliativo a la desintegración de los barcos varados, el óxido de los puentes y las pasarelas, la mansa atrofia de los cascos grasientos y chapa roída. Dos metros por encima de la superficie estancada, la luz marrón de los vahos petroquímicos confluía con el verde de las hojas en un limbo amarillento donde las fábricas huecas, los frigoríficos fantasmas y las filas taperas ganaban una definición casi anímica. (Cohen, “La ciencia ficción” 156)
\end{abstract}

Esta visión provoca inicialmente cierta melancolía, la intuición de que ya nada bueno puede anticiparse, de que el futuro ya se ha consumado en el riachuelo o es simplemente la amplificación de lo mismo. La alegoría entonces se explicita y desenvuelve históricamente, amplía su contexto significativo: el riachuelo pasa a representar el fracaso de la humanidad: "Es más bien la seguridad de que el mundo ha fracasado, como si el hombre concebido por el titanismo renacentista y realimentado por la ilustración hubiera probado de demasiadas formas su incompetencia” (158).

En ese marco se inserta el tema central del artículo, el género de anticipación y sus últimos desarrollos; el género que recuerda, pese a sus desfallecimientos, sus errores prospectivos, e incluso, “el decaimiento de su energía inductora en la aurora del 2000” y sus repeticiones caducas, que el futuro siempre está abierto y puede volver a modelarse: "En las ficciones fantásticas que al contrario que los mitos y las teorías no regulan conductas, el horizonte temporal no es inamovible. Es rediseñeable y reconstituíble, como los edificios tubulares, como la familia contemporánea” (162).

Cohen pasa entonces a valorar los aportes de los representantes de la Nueva ola, algunos de los cuales son claves en su propia poética y aparecen trabajados en la mayor parte de sus textos: interés por un futuro próximo y el espacio interior, uso restringido de la ciencia y la tecnología; importancia de la descripción, contigüidad entre espacio de las superficies y espacio interior. Aportes que considera abortados por la posterior corriente ciberpunk, cuya mejor contribución fue constatar que el rasgo característico de la era, no es el robot, como lo suponía la ciencia ficción clásica, sino la PC y su consecuencia: la exploración del ciberespacio-un rasgo explotado porCohen, por ejemplo, en Donde yo no estaba, una novela/diario en la que los personajes suelen enchufarse a la "panconciencia", son por momentos, especies de hackers de conciencias ajenas-;

\begin{tabular}{l} 
Revista Iberoamericana, Vol. LXXX, Núm. 247, Abril-Junio 2014, $399-432$ \\
\hline ISSN 0034-9631 (Impreso)
\end{tabular} 
y su peor legado lo constituyen, bajo la bandera del retorno a la narratividad, tanto las "historias con finales y comienzos rotundos" -fábulas fuertemente trabadas, de las que Cohen reniega en varios trabajos críticos-, como un muestrario de los últimos productos de consumo impuestos por el sueño americano -videoclip, travesuras anarcoides de hackers, tribus del hip hop o rock asistido por sintetizador.

Finalmente, otro fragmento espacial latinoamericano viene a conectarse con la alegoría inicial para corroborar la certeza de fracaso. Ahora es la ciudad de Bogotá, donde se detiene la mirada para reanimar luego la reflexión sobre el arte, a través de una frenética y caótica descripción en largos segmentos heterogéneos:

Cajeros automáticos (¡robots!), bares nocturnos repletos, batidos, salsa y tecnomúsica, publicidad por pantalla, barbeches, mulatos en mountainbike, señoritas en Pathfinder, provectos señores rasposos; niños llamados desechables, embobados, ateridos, que asoman de las cloacas en donde viven para sentarse en un cajón, entre las casuchas de la ladera, a contemplar la llovizna, los edificios difusos, la eterna congestión del tráfico allá abajo; frijoles rancheros y bruschetta con calamares. Todo en un país desmembrado en feudos, tapizado de cadáveres y cadáveres, roto en zonas casi autónomas donde dominan los narcos o se consolidan las guerrillas, donde la guerrilla pacta con los narcos, los narcos con el ejército o el ejército con la guerrilla, lejos del poder enclaustrado, la impotencia organizativa y la terquedad autista del aparato estatal; lejos de un remedo estatal de continuidad democrática. (170)

Bogotá, otra alegoría, naturaleza fragmentada y confusa que tiende a totalizarse: lo que allí se ve, dice Cohen, es el "hoy de buena parte del mundo" (171). Una realidad, una forma, que califica como “descriptible pero indefinible” (171).

Al poner en conflicto estas dos facultades, la de definir y la de describir, Cohen parece hacer explotar, subvirtiéndolo, el sentimiento de lo sublime kantiano; aquél que tiene lugar, por el contrario, cuando la imaginación fracasa y no consigue presentar un objeto que, aunque más no sea en principio venga a establecerse de acuerdo con un concepto. Si lo sublime, afección fuerte y equívoca que conlleva a la vez placer y pena, supone la existencia de ideas que no tienen presentación posible, que son impresentables, que no nos dan a conocer nada de la realidad, prohíben el libre acuerdo de las facultades que produce el sentimiento de lo bello, impiden la formación y la estabilización del gusto; ${ }^{40}$ hay aquí una total inconmensurabilidad de la realidad en relación con el concepto, hay quizá la gestación de un nuevo sublime, un más sublime, o pos-sublime en tanto esa realidad es “excepcionalidad de la sinrazón”, un daño acompañado por la pérdida de los medios de presentar la prueba del daño, "fracaso de las categorías de la razón”, del proyecto moderno y sus diversos modos de racionalización instrumental,

${ }^{40}$ Véase Lyotard, "Lo sublime y la vanguardia”.

Revista Iberoamericana, Vol. LXXX, Núm. 247, Abril-Junio 2014, $399-432$
ISSN 0034-9631 (Impreso)


“imaginación hecha tumor”, "algo sólo accesible a la descripción paciente o el rodeo por la fantasía” (171).

Este indefinible pondría en evidencia otros fracasos; hecha por tierra, según Cohen, diversas variantes estéticas que resultan falsas en su impotencia o su inocencia: el exotismo, el relato maravilloso, el costumbrismo, el grotesco colorista, la literatura de denuncia e inclusive la literatura de anticipación del siglo xx.

Lo que se expone desde el principio del artículo, entonces es una continua sucesión de fracasos: fracaso de la razón en la realidad, fracasos políticos y económicos, fracasos artísticos.

La poética de Cohen no se detiene sin embargo en estas constataciones, ni éstas se traducen en sus textos en alegorías, expresiones estéticas de la desesperanza, de la derrota literaria y política. ${ }^{41}$ Lo alegórico, el fracaso, no supone un eterno transitorio, totalidad negativa, emblema de muerte y decadencia; deviene en todo caso un momento, una faz, alterables por movimientos imprevisibles. Porque lo alegórico queda contenido y modificado en los horizontes científicos de las teorías del caos:

Una vida sobrenatural se gesta en esa vida que nos contiene [...] Toda vida tiene la ocasión de procesar el mal con el que ha nacido [...] Ahora empezamos a saber, entre otras cosas, que nuestros tiempos son combinaciones de tiempos diversos. Según las leyes de Newton, se levantan y acuestan con el sol; de acuerdo con el segundo principio de la termodinámica, contienen relojes físico-químicos, se descomponen en recorridos contradictorios y rápidos, mueren exhaustos y arrugados; pero imprevisiblemente, a veces se reproducen en hijos mejores que ellos. No sólo nosotros somos agregados de sistemas y funcionamientos particulares, sin fundamento; así es todo lo real, y con nuestra acción nos hacemos y hacemos de lo real un mundo o un medio para nosotros. En los modelos que contemplan la vaguedad, la liquidez, el flujo, la insustancialidad última de lo existente hay una gramática para los mitos provisorios del nuevo futuro. (Cohen, Realmente fantástico 171)

Las teorías del caos -que ya habían dado sustento a su noción de realismo inseguro o abarcador, aquél que anula la oposición realismo/fantástico, explota la descripción morosa por sobre los fuertes nudos del relato y se convierte en la expresión más ajustada a una realidad presente, al paisaje posindustrial o del capitalismo tardío, de ruina y de mezcla- se reafirman aquí al constituir una instancia superadora con la que la alegoría queda transvalorada, por no estar ya sujeta a una teleología decadente y, lejos de la melancolía, del escepticismo o pesimismo finisecular, instauran un nuevo sublime, afección equívoca en la que la certeza del fracaso, esa "excepcionalidad de

${ }^{41}$ Véase Avelar, Alegorías de la derrota.

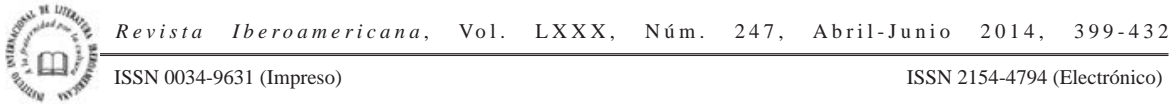


la sinrazón”, no es mayor -al contrario parece exigirlo más- que el compromiso con el trabajo imaginativo.

Para comprobarlo bastará detenerse en “Rigor y aventura”, un artículo que escrito diez años después, demuestra la continuidad de un proyecto narrativo donde las posibilidades de lo literario vuelven a jugarse en relación a determinados ciclos históricos o momentos de crisis de la civilización. "La ciencia ficción y los restos del porvenir” se adelantaba al advenimiento del nuevo milenio con sus mitos, fantasías y temores, respondía a un clima de balance, de ajuste de cuentas, a la sensación generalizada de derrota de la civilización occidental. "Rigor y aventura”, publicado en otoño del 2009, responde a un fracaso muy preciso, al cataclismo del Capital, y a algunas posiciones con respecto a la literatura que éste generó, más precisamente a una tendencia apocalíptica que Cohen percibe como dominante y a la que se enfrenta. Se trata ahora de un posible Apocalipsis de la literatura -no simplemente de una literatura del Apocalipsis-, de un salirse de la literatura, destruir los valores de su tradición, entregándose directamente a escribir mal, “o sea contra los parámetros estéticos de escritura” (29). Tal posición, que barre con los valores y sostiene lo literario en la arbitrariedad del deseo del escritor o del crítico, para Cohen es tan inadecuada como aquélla a la que ésta se opone: la literatura como “proveeduría de las bellas letras". Al desastre del capital no le debe corresponder su doble complementario, un desastre total de la literatura. Cohen pretende evitar la caída de la literatura en un afuera contaminante de lenguajes - "jergas desafiantes, oralidad brutal" (31) que colonizan radios y publicidades-, y que, básicamente reproductivos del sistema, implican una confiscación de sus poderes. El afuera es la vida capitalista con sus relatos desechables, tanto las "ficciones de masas" plagadas de tópicos, y simplismo sintáctico "anacolutos; redundancias y solecismos al servicio de la vaguedad o la superposición de significados” (31), como aquéllas que con gesto indiferente, ocultan esa vida con adornos verbales y lenguaje sazonado; más, las jergas e historias de los medios masivos.

Como en "La ciencia ficción y los restos del porvenir" hay también aquí una apuesta y un compromiso, quizás más extremos, porque está en juego ahora el posible fracaso de lo literario que en Cohen es más que nada la progresiva asimilación, en ese espacio, de la ley del capitalismo: la repetición de lo mismo. La actitud ante el fracaso, un "sistema que nos acogota” y que promete "una enormidad de crepúsculo" (29), es la misma que en "La ciencia ficción y los restos del porvenir": mayor esfuerzo imaginativo para lograr algo de "luz".

Con estas metáforas de aliento renacentista, se introduce una especie de política erótica de escritura, basada en el sentido etimológico del término “ocupación”. Para salir de las sombras epocales, el escritor deberá ocuparse, es decir, obrar con cuidado, cuidar las formas, amarlas, lo que implica al mismo tiempo "romper con los adornos verbales que apuntalan el estropicio, pero impidiendo que los estropicios del sistema afecten a lo mejor de lo que ha existido para evitarlo" (29). En vez del éxodo, a la literatura le queda

Revista Iberoamericana, Vol. LXXX, Núm. 247, Abril-Junio 2014, $399-432$
ISSN 0034-9631 (Impreso) 
su propio espacio interior, su tarea específica: inventar que exige hoy la práctica de una narración “cuidada”, una "buena narración”, una narración "bien hecha”, que ya de por sí, ante ese complejo exterior de historias falsas, constituye un acontecimiento -lo que en Cohen es fundamentalmente un extrañamiento, desautomatización de la percepción, ataque a los sentidos embotados por el sistema y apertura a nuevas sensaciones o a un imposible, en el sentido de ajeno a la doxa. Por eso, la bondad de una narración no deriva de la calidad de los materiales, de la pericia de su tratamiento o del seguimiento de los grandes modelos de la tradición. El mejor ejemplo de una narración cuidada es el Ulises; el texto que siendo "a la vez, excelencia máxima y soberano desorden destructivo”, "aún enseña que la buena narración no radica en la confección acabada, claro que no, sino en el espacio que el afán de perfección cede a lo incondicionado. En cada párrafo del libro mejor hecho hay un aliento, un aleteo, una necesidad, producto del roce con lo que no es lenguaje" (31).

Es ése el modo en que la escritura puede adquirir dimensión política, empleando un "lenguaje rescatado de confiscaciones, pudibundeces y abusos" (34), un lenguaje que afanosa, amorosamente trabajado, devuelva la palabra al mundo, sin fundirse con él, o, lo que es lo mismo, lo rememore o lo prefigure. Así “ocupación”, aunque Cohen no lo explicite, se suma al esquema espacial ya aludido (adentro/afuera), y adquiere las connotaciones de su sentido político militar: sólo permaneciendo en su ámbito, la literatura podrá establecer formas siempre provisorias de permanencia en un territorio ajeno (aquí el afuera de la literatura) y sin anexionarlo, intervenir en su vida pública, esto es proveer discursos para la intemperie: "El amor por las formas que puede cobrar una lengua es una intervención directa en la arena donde poder crudo y sueños de comunidad libran una lucha interminable” (31).

\section{INTEMPESTIVA POÉTICA}

La peculiar configuración que adquiere la experiencia de la derrota en la ciencia ficción contrautópica de Cohen de los años noventa, guarda estrecha relación con la actitud asumida ante los diversos fracasos sobre los que discurre la conciencia teórico/ crítica, según los principios que guían la formulación de un "realismo inseguro", como respuesta, en la posdictadura, a la ineficacia del realismo tradicional, lo real maravilloso, la literatura de denuncia, u otros formatos como novelas históricas o variantes del testimonio que giran en torno a la derrota, las figuras de fracasados o perdedores o hacen de un estado de memoria, en duelo o melancólica -aunque sea un gesto político, crítico, resistente y creativo-, el eje de lo literario.42

${ }^{42}$ Véanse Pons, Memorias del olvido; Avelar, Alegorías de la derrota; Amar Sánchez, Instrucciones para la derrota, y Ette y otros, Poéticas del fracaso.

Revista Iberoamericana, Vol. LXXX, Núm. 247, Abril-Junio 2014, $399-432$
ISSN 2154-4794 (Electrónico) 
Ya “El porvenir es más duro que el granito”, donde la escritura se fragua en la pérdida y se avizora melancólicamente la derrota, se advierte cómo Cohen, bajo la impronta de los talleres "Mario de Lellis", donde inicia sus prácticas con la literatura, si bien adoptaba el "compromiso de ser un poeta militante", aprendía también "que el origen de toda literatura es la realidad, pero que la realidad de la literatura es el lenguaje, que la literatura es una artesanía, una convención, una irrealidad” (Castillo 3). Esa convicción temprana, evidente en las referencias a Pavese y en la insistencia del protagonista en la necesidad de consustansiarse en el trabajo con las palabras, reaparece -enriquecida ya por múltiples lecturas provenientes del psicoanálisis, la filosofía, la teoría literaria, las ciencias, los desarrollos de otras artes-, en la defensa de una "narración cuidada", como resguardo ante el avance de la "mala escritura". De ahí las críticas a las ingenuas morales literarias que tienen los objetivos de re-describir acontecimientos reales tal como verdaderamente son, a través de una representación verosímil; llegar a representar las causas profundas; actuar sobre la realidad o develarla, ir al encuentro de un sentido previo o de una verdad sustancial identificable; serle al mundo lo más fiel posible y de este modo beneficiar a los desposeídos, a todos los que están abrumados por las tergiversaciones, por las deformaciones, manipuladoras de información, los saberes encapsulados y los relatos de los vencedores. De ahí también el rechazo a las que se juegan en la propuesta de un éxodo de lo literario, refritando lenguajes empobrecidos de lo siempre igual.

Sin embargo, la literatura de Cohen, no está exenta de inquietudes sociopolíticas, no abandona las alusiones al exilio, a discursos y prácticas relacionados tanto con el accionar represivo del estado argentino, como con los ideales o actos de resistencia de los vencidos, ni las explícitas ocurrencias de los términos derrota o derrotado. ${ }^{43}$ Puede incluso leerse en su producción una cierta continuidad entre la inicial representación de situaciones vinculadas a la represión militar y las acciones represivas de las sociedades de control, características de sus textos de los noventa en los que también se presentan grupos clandestinos, subversivos. ${ }^{44}$ Sólo que su realismo inseguro, más que volver al pasado para repararlo en sus injusticias y silencios o hacerlo objeto único y constante de reflexión o representación, desconfía de las totalizaciones restauradoras y prefiere explotar las posibilidades que aún entre despojos, pérdidas, ruinas, escombros o deshechos, ofrece el presente. ${ }^{45}$ Por eso la derrota o ese período de la historia argentina, es en sus

${ }^{43}$ Véase El país de la dama eléctrica (1984) e Insomnio (1986).

${ }^{44}$ Véase Chiani, "De la represión de la dictadura militar a la represión de la sociedad posindustrial”.

${ }^{45}$ En el año 2001, Cohen afirmaba "La salida está en el presente (que es lo que supuestamente aflige al público incluso) y en sus opciones inmediatas. El medio físico, la contaminación de la mente, el entumecimiento del lenguaje y la sensación, el prodigio de la sensación cuando aparece. No retroceder, ni adelantarse: escribir como modo de estar en las cosas [...] en Argentina la producción de mitos es tan copiosa y rápida que vale la pena preguntarse si cualquier ficción retrospectiva, obsesionada por el

Revista Iberoamericana, Vol. LXXX, Núm. 247, Abril-Junio 2014, $399-432$
ISSN 0034-9631 (Impreso) 
ficciones, eso, pasado del presente de la acción -tal como se rubrica con la alusión a la flecha del tiempo, tomada de las teorías del caos-, irreversible en lo que respecta a los objetivos y prácticas revolucionarias que, por lo demás, lejos de ser idealizados, o actualizados, son, en algunos casos, materia controvertida o inconducente en los nuevos contextos opresivos de sus ficciones. ${ }^{46} \mathrm{Y}$ es también irreversible para una literatura, que rememora pero sin melancolía, ya liberada y sin inhibiciones, capaz de depositar la libido sobre nuevos objetos, y de recactetizar el mundo; y que se concibe, más que como un acto de memoria, como un acto de imaginación nacido justamente de la insatisfacción con el orden de la realidad.

El exceso de una memoria voluntaria, se vuelve perjudicial en un sistema que hace de ésta también un negocio o un espectáculo. Tanto Inolvidables veladas como una de sus últimas novelas, Impureza, son textos en los que los protagonistas realizan trayectos para desembarazarse de cultos memorísticos impuestos que, a modo nietzscheano, implican "una rumia del pasado”, una conciencia de la repetición que paraliza y enferma.

pasado, las raíces de la conducta y el medio social, torturada por lejanos pecados de comisión y omisión, por los precedentes, no va a ofrecer siempre un aspecto más bien cadavérico -cuando muertos ya tenemos de sobra” (Cohen, "En opaco" 60).

${ }^{46}$ En "Pequeñas batallas por la propiedad de la lengua" -un artículo en el que Cohen da cuenta de los procesos culturales y políticos, de carácter personal, desatados en el exilio en España, un potente catalizador de posicionamientos con respecto a la traducción y la escritura- hace referencia a una etapa de crítica del "izquierdismo", que puede vincularse a los modos de inserción de los discursos políticos de los setenta y a las configuraciones de la derrota en algunos de los textos de los noventa: "muchos habíamos reaccionado ante la derrota argentina con un contra aprendizaje acelerado. El clima libertario de la España de fines de los setenta lo había favorecido: una casi inmediata crítica de la ideología, que en mi caso comprendía no sólo el leninismo, todos los socialismos reales y la filosofía de la toma del poder, sino los apéndices locales de porteñismo integrista, machismo familiero, verticalismo militarista, violencia sexual, sentimentalismo, culto de la pasión impúdica, represión pequeñoburguesa generalizada. Todo esto iba a cuajar en un programa de ampliación de la conciencia, de intento de destrucción de los paradigmas, que estuviera a la altura de un deseo de independencia imposible de soslayar. Este programa multifacético iba cuajando eslóganes fragmentarios. En la idea, por ejemplo, de que no se trataba de cambiar la realidad para poder seguir siendo como éramos, sino de cambiar nosotros para hacer posible otra realidad" (47). En "Donde se realizan los sueños", un cuento de El buitre en invierno de 1985, ya se registra en su narrativa esta crítica, en términos muy similares a la realizada en El testamento de O'Jaral. El texto introduce controvertidamente el papel de la izquierda durante la etapa de la dictadura, en un discurso autobiográfico del protagonista, quien se fuga a una isla con dinero sucio de la guerrilla, después de raptar a dos alemanas: "Lo que pasa es que hace mucho me vendieron un buzón y me convencieron de que había que luchar por los ideales. El socialismo, la justicia, tirar los imperialistas a un foso, mambos por el estilo. Quería ser héroe, flacas. Siempre quise ser héroe. Ahora no, ya se me bajaron los humos, pero antes quería ser un héroe de la gran siete. Los muchachos se entusiasmaron con nuestra eficacia y empezaron a mandarnos todos los días al frente. No explicaban un carajo: que boletear un milico, que asaltar un banco, que patatín, patatán; y basta. Lógicamente nos cansamos, uno es idealista pero no idiota. Quisieron meternos en una cárcel del pueblo -íbamos a tener que hacernos la autocrítica revolucionaria. ¿Pero a papá mono con bananas verdes? ¿No tuvimos más remedio que rajarnos del país con dinero de ellos” (Cohen, El buitre 15).

Q Revista Iberoamericana, Vol. LXXX, Núm. 247, Abril-Junio 2014, 399-432 ISSN 0034-9631 (Impreso) 
En Cohen, como en Nietzsche, no se tata de negar el sentido histórico, sino de contenerlo, encauzarlo, devolverlo a sus exactos límites. ${ }^{47}$ "El sentido histórico y su negación son igualmente necesarios para la salud de un individuo, de un pueblo, de una civilización” (Nietzsche 209).

También ese doble movimiento sostiene esta poética narrativa que lejos de cualquier progresismo optimista, descansa en la serena certeza de que -tras los fracasos y más allá de cualquier derrota pasada o presente-, lo verdaderamente real es la posibilidad incesante; y en la confianza de que la dimensión política de una escritura se juega especialmente en la rebeldía de sus lenguajes y formas, frente a los relatos hegemónicos que reducen y detienen el mundo con su ramplona y falaz repetición.

\section{BiBLIOGRAFÍA}

Amar Sánchez, Ana María. Instrucciones para la derrota. Narrativas éticas y políticas de perdedores. Barcelona: Anthropos, 2010.

Avelar, Idelber. Alegorías de la derrota: la ficción posdictatorial y el trabajo del duelo. Santiago: Editorial Cuarto Propio, 2000.

Boletín/12 del Centro de Estudio de Teoría y Crítica Literaria, Rosario, 2006.

Benjamin, Walter. "El narrador". Para una crítica de la violencia y otros ensayos. Iluminaciones IV. Madrid: Taurus, 1992. 111-135.

El origen del drama barroco alemán. Madrid: Taurus, 1991.

Berman, Marshal. Todo lo sólido se desvanece en el aire. Buenos Aires: Siglo XXI, 1998.

Berg, Eduardo. “Los relatos de la ciudad: papeles de trabajo”. Espéculo. Revista de estudios literarios 42 (2009). <http://www.ucm.es/info/especulo/numero42/relaciud.html>.

Borges, Jorge Luis y otros. El arte después de la modernidad. Nuevos planteamientos en torno a la representación. Brian Wallis, ed. Madrid: AKAL, 2001.

Bracamonte, Jorge. “Narraciones argentinas contemporáneas: memorias, identidades y espacios utópicos". Prepared for delivery at the 2000 meeting of the Latin American Studies Association, Hyatt Regency Miami, March 16-18, 2000.

Capanna, Pablo. "La ciencia ficción y los argentinos”. Minotauro 10 (1985): 43-58.

Caparrós Martín. "Nuevos avances y retrocesos de la nueva novela argentina en lo que va del mes de abril”. Babel II/10 (1989): 43-45.

Caplán, R. y otros. Univers répressifs. Péninsule ibérique et Amérique Latine. R. Caplán, M. L. Copete, I. Reck, coords. París: L’Harmattan, 2001.

Castillo, Abelardo. Prólogo. Marcelo Cohen. Lo que queda. Buenos Aires: LH S.R.L, 1973. 3-7.

\footnotetext{
47 Véase Lacoue Labarthe, "Historia y Mimesis".
}

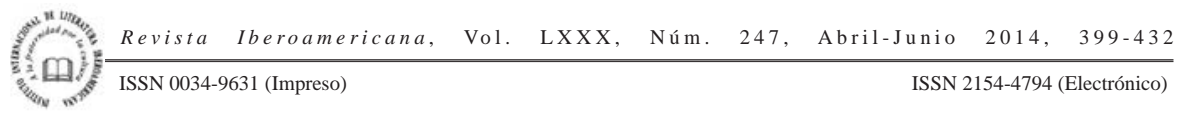


Cohen, Marcelo. “Como si empezáramos de nuevo. Apuntes por un realismo inseguro”. Realmente fantástico y otros ensayos. Buenos Aires: Norma, 2003. 129-155.

Donde yo no estaba Buenos Aires: Norma, 2006.

El buitre en invierno. Barcelona: Montesinos, 1985.

El fin de lo mismo. Buenos Aires: Alianza, 1992.

El país de la dama eléctrica. 1984. Buenos Aires: Interzona, 2004.

“El porvenir es más duro que el granito”. Los pájaros también se comen. Buenos

Aires: Editorial Boedo, 1975. 57-75.

El testamento de O'Jaral. Buenos Aires: Alianza, 1995.

“En opaco mediodía”. Mil palabras I/1 (2001): 49-62.

Hombres amables. Dos incursiones de Georges La Mente. Buenos Aires: Norma, 1998.

Impureza. Buenos Aires: Norma, 2008.

Inolvidables veladas. Madrid: Minotauro, 1996.

Insomnio. 1986. Buenos Aires: Paradiso, 1994.

"La ciencia ficción y los restos del porvenir". 1999. Realmente fantástico y otros

ensayos. Buenos Aires: Norma, 2003. 156-174.

"La ilusión monarca”. El fin de lo mismo. Buenos Aires: Alianza, 1992. 9-120.

“La novela como hipótesis. Entrevista de Hernán Arias”. Perfil (domingo 4 de

noviembre de 2007): Cultura/Literatura-5.

"La orfandad como repetición y salida”. Otra parte 7 (2005): 39-44.

Lo que queda. Buenos Aires: Ediciones LH S.R.L, 1973.

Los pájaros también se comen. Buenos Aires: Editorial Boedo, 1975.

"Pequeñas batallas por la propiedad de la lengua”. Poéticas de la distancia.

Adentro y afuera de la literatura argentina. Sylvia Molloy y Mariano Siskin, eds.

Buenos Aires: Norma, 2006. 35-55.

"Prosa de Estado y estados de la prosa". Otra parte 8 (2006): 1-8.

Realmente fantástico y otros ensayos. Buenos Aires: Norma, 2003.

"Rigor y aventura”, Otra parte 17 (2009): 28-34.

Chiani Miriam. "La fiesta seminal de las palabras". Fines de siglo y Modernismo:

Congreso Interancional Buenos Aires-La Plata, agosto 1996. Volumen II. María

Payeras Grau y Luis Miguel Fernández Ripoll, eds. Palma de Mallorca: Universitat de les Illes Balears, 2001. 719-724.

"De la represión de la dictadura militar a la represión en la sociedad posindustrial. Modulaciones en el imaginario de la opresión en los relatos de Marcelo Cohen”. Univers répressifs. Péninsule ibérique et Amérique latine. R. Caplán, M.L. Copete,I Reck, coord. París: L’Harmattan, 2001. 139-152.

Dalmaroni, Miguel. “El imperativo y sus destiempos”. Anclajes VI/6 Parte II (2002).

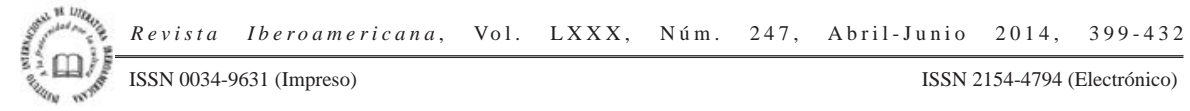


Dellepiane, Ángela. "Narrativa argentina de ciencia ficción: tentativas liminares y desarrollo posterior”. AIH. Actas IX. Centro virtual Cervantes, 515-525. <http:// cvc.cervantes.es/literatura/aih/pdf/09/aih_09_2_059.pdf>.

Diego, José Luis de. Quién de nosotros escribirá el Facundo. Intelectuales y escritores en la Argentina (1970-1986). Buenos Aires: Al Margen, 2003.

Ette, Ottmar y otros. Poéticas del fracaso. Yvette Sánchez y Roland Spiller, eds. Tubinga: Günter Narr Verlag, 2009.

Fabry Geneviève y Ilse Logie. "Los imaginarios apocalípticos en la narrativa hispanoamericana contemporánea(s. XX-XXI). Una introducción”. Los imaginarios apocalípticos en la narrativa hispanoamericana contemporánea. Geneviève Fabry, Ilse Logie y Pablo Decock, eds. Bern: Peter Lang, 2010. 11-30. y otros. Los imaginarios apocalípticos en la narrativa hispanoamericana contemporánea. Geneviève Fabry, Ilse Logie y Pablo Decock, eds. Bern: Peter Lang, 2010.

Fin(es) de siglo y Modernismo: Congreso Internacional Buenos Aires-La Plata, agosto 1996. María Payeras Grau y Luis Miguel Fernández Ripoll, eds. Palma de Mallorca: Universitat de les Illes Balears, 2001.

Freud, Sigmund. “Duelo y melancolía”. Obras completas. Volumen XIV. Buenos Aires/ Madrid: Amorrortu, 1982. 112-135.

Obras completas. Buenos Aires/Madrid: Amorrortu, 1982.

Gramuglio, María Teresa. "El realismo y sus destiempos en la literatura argentina". Historia crítica de la literatura argentina. Noé Jitrik, dir. Vol. 6 - El imperio realista. M. T. Gramuglio, dir. Buenos Aires: Emecé, 2002. 15-38.

Jameson, Fredric. "Progreso versus utopía: ¿podemos imaginar el futuro?” El arte después de la modernidad. Nuevos planteamientos en torno a la representación. Brian Wallis, ed. Madrid: AKAL, 2001. 241-248.

Teoría de la posmodernidad. Madrid: Trotta, 1996.

Lacoue Labarthe, Philippe. "Historia y Mimesis". Instantes y azares. Escrituras nietzscheanas X/6-7 (2009): 15-37.

Landsberg, P. T. y otros. Proceso al azar. Jorge Wagensberg, ed. Buenos Aires: Tusquets, 1992.

Ludmer, Iris Josefina. “Territorios del presente en la isla urbana”. Pensamiento de los Confines 15 (2004): 103-110.

Lyotard, Jean-François. La posmodernidad explicada a los niños. Barcelona: Gedisa, 1992. "Lo sublime y la vanguardia”. La posmodernidad explicada a los niños. Barcelona: Gedisa, 1992. 19-26.

Matamoro, Blas. "Literatura y compromiso". Letras libres (2002). <http://www. letraslibres.com/index.php?art=7345\&red=2>.

Molloy, Sylvia y otros. Poéticas de la distancia. Adentro y afuera de la literatura argentina. Sylvia Molloy, Mariano Siskind, eds. Buenos Aires: Norma, 2006. 35-55.

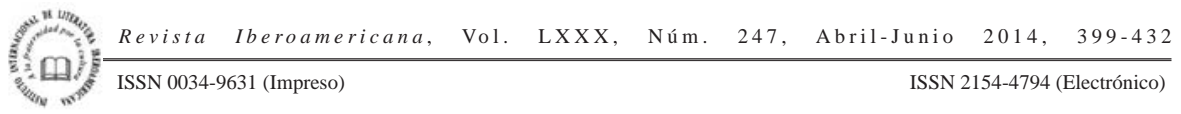


Nietzsche, Friedrich. Sobre la utilidad y el perjuicio de la historia para la vida. II Intempestiva. Traducción y notas de G. Cano. Madrid: Biblioteca Nueva, 1999.

Oeyen Annelies. “Imágenes de la barbarie en 'La ilusión monarca’ de Marcelo Cohen”. Los imaginarios apocalípticos en la narrativa hispanoamericana contemporánea. Geneviève Fabry, Ilse Logie y Pablo Decock, eds. Bern: Peter Lang, 2010. 257-267.

Patiño, Roxana "Intelectuales en transición. Las revistas culturales argentinas (19811987)”. Cuadernos de Recienvenido 4 (1997), Universidad de San Pablo. <www. revistasculturales.com/articulos/37/insula/596/4/re...>.

Pinkney, Tony. "Modernismo y teoría cultural”. Raymond Williams. La política del Modernismo. Contra los nuevos conformistas. Buenos Aires: Manantial, 1989.15-49.

Pons, María Cristina. "Neoliberalismo y producción cultural (segunda parte)”. Espéculo. Revista de estudios literarios 41 (2009). <http://www.ucm.es/info/especulo/ numero41/neolibe2.html>.

Memorias del olvido. La novela histórica de fines del siglo XX. México: Siglo XXI, 1996.

“¿El fin de la ciencia?”. Nuevos paradigmas, cultura y subjetividad. Buenos Aires: Paidós, 1994.

Prigogine, Ilya. "Enfrentándose con lo irracional”. AAVV Proceso al azar. Buenos Aires: Tusquets, 1992.

e Isabelle Stengers. La nueva alianza. Metamorfosis de la ciencia. 1983. Madrid: Alianza universidad, 1994.

Reati, Fernando. Postales del porvenir. La literatura de anticipación en la Argentina neoliberal (1985-1999). Buenos Aires: Biblos, 2006.

Saítta, Sylvia. "La narración de la pobreza en la literatura argentina del siglo XX". Revista Nuestra América 2 (2006): 89-102

Sánchez, Silvina. “'Iniciar por fin el éxodo’: 'prosa de Estado’ y literatura en Marcelo Cohen”. La Plata: Mimeo, 2010.

Sarlo, Beatriz. Escritos sobre literatura argentina. Buenos Aires: Siglo XXI, 2007. "La novela después de la historia. Sujetos y tecnologías". Escritos sobre literatura argentina. Buenos Aires: Siglo XXI, 2007. 471-482.

"Una patria, una canción”. Escritos sobre literatura argentina. Buenos Aires: Siglo XXI, 2007. 387-390.

Sassi, Hernán. "A pesar de Shangai, a pesar de Babel”. Pensamiento de los Confines, 18 (2006) <www.elinterpretador.net/32HernanSassi-APesarDeShanghai> .

Steimberg,Alejo. "El postapocalipsis rioplatense de Marcelo Cohen. Una lectura de Donde yo no estaba". Los imaginarios apocalípticos en la narrativa hispanoamericana contemporánea. Geneviève Fabry, Ilse Logie y Pablo Decock, eds. Bern: Peter Lang, 2010. 245-255.

Vattimo, Gianni. Ética de la interpretación. Buenos Aires: Paidós, 1992.

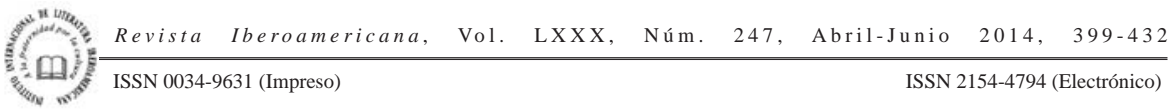


“Utopía, contrautopía, ironía”. Ética de la interpretación. Buenos Aires: Paidós, 1992. 95-112.

Williams, Raymond La política del Modernismo. Contra los nuevos conformistas. Buenos Aires: Manantial, 1989.

Revista Iberoamericana, Vol. LXXX, Núm. 247, Abril-Junio 2014, 399-432 ISSN 0034-9631 (Impreso) 